\author{
UNIVERSIDADE DE SÃO PAULO \\ ESCOLA DE ENFERMAGEM DE RIBEIRÃO PRETO
}

TALITHA BORDINI DE MELLO

Comunicação de más notícias: experiências de mães de crianças e adolescentes com câncer

RIBEIRÃO PRETO 
TALITHA BORDINI DE MELLO

\title{
Comunicação de más notícias: experiências de mães de crianças e adolescentes com câncer
}

\author{
Dissertação apresentada à Escola de \\ Enfermagem de Ribeirão Preto da \\ Universidade de São Paulo para obtenção \\ do título de Mestre em Ciências, Programa \\ de Pós-Graduação Enfermagem em Saúde \\ Pública.
}

Linha de Pesquisa: Assistência à criança e ao adolescente

Orientadora: Prof ${ }^{\mathrm{a}}$. Dr ${ }^{\mathrm{a}}$. Regina Aparecida Garcia de Lima

\section{RIBEIRÃO PRETO}


Autorizo a reprodução e divulgação total ou parcial deste trabalho, por qualquer meio convencional ou eletrônico, para fins de estudo e pesquisa, desde que citada a fonte.

Mello, Talitha Bordini de

Comunicação de más notícias: experiência de mães de crianças e adolescentes com câncer. Ribeirão Preto, 2013.

89 p. : il. ; 30cm

Dissertação de Mestrado, apresentada à Escola de Enfermagem de Ribeirão Preto da Universidade de São Paulo. Área de concentração: Enfermagem.

Orientadora: Profa Dra Regina Aparecida Garcia de Lima.

1. Comunicação. 2. Câncer. 3. Criança. 4. Adolescente.

5. Enfermagem. 6. Mães. 
MELLO, Talitha Bordini de

Comunicação de más notícias: experiências de mães de crianças e adolescentes com câncer

Dissertação apresentada à Escola de

Enfermagem de Ribeirão Preto da

Universidade de São Paulo para obtenção do

título de Mestre em Ciências, Programa de

Pós-Graduação Enfermagem em Saúde

Pública.

Aprovada em:

\section{Banca Examinadora}

Prof. Dr.

Instituição:

Julgamento:

Assinatura:

Prof. Dr.

Instituição:

Julgamento:

Assinatura:

Prof. Dr.

Instituição:

Julgamento:

Assinatura: 


\section{DEDICATÓRIA}

À minha mãe por todo amor e por ter me tornado a pessoa que sou hoje e sempre acreditar nas minhas escolhas e conquistas.

Ao meu pai, sempre vivo em minha memória e no meu coração.

Aos meus irmãos, Camila e Théo, pelo amor, amizade, compreensão, incentivo, carinho, companheirismo, aprendizado e sabedoria.

Às minhas avós, Emília e Aparecida, por todo amor, carinho, dedicação e ensinamentos.

Às minhas tias e tios, pessoas especiais na minha vida, pela compreensão, amor, por acreditarem, incentivarem e apoiarem minhas escolhas.

Ao meu querido sobrinho, Leonardo, por todo amor e carinho e por alegrar minha vida e deixar meus dias mais coloridos.

Às mães que participaram da pesquisa e tornaram esse trabalho possível, pelo acolhimento e confiança ao se colocarem de coração aberto para compartilhar suas histórias, vivências, ansiedades e medos.

E às crianças e adolescentes com câncer, "pessoinhas” iluminadas que mesmo com a doença e com as dificuldades não perdem a alegria e doçura de viver, sempre me ensinaram muito e mostraram a vontade de viver. 


\section{AGRADECIMENTOS}

A Deus por guiar meus passos e me proporcionar força, equílibrio e serenidade.

À minha orientadora, Profa Dra Regina Aparecida Garcia de Lima, por acreditar em mim desde a graduação, por ter me incentivado e ensinado, compartilhando seus conhecimentos $e$ experiências, ajudando a finalizar esse trabalho com sabedoria e dedicação. Deixo aqui meu agradecimento e grande admiração.

À Profa Dra Lucila Castanheira Nascimento e Enfa Dra Juliana Cardeal da Costa Zorzo pela disponibilidade e colaboração com críticas e sugestões no Exame de Qualificação, as quais contribuíram para continuidade e finalização deste trabalho.

À Profa Dra Maria Cândida Carvalho Furtado, pelo carinho, apoio, compreensão, estímulo, ensinamentos e pelo acolhimento em momentos difíceis.

Ao Marcelo, pelo amor, confiança, paciência, compreensão e colaboração, e por tornar meu porto seguro.

Às enfermeiras da pediatria, Maria José Menossi, Juliana, Hilda, Fernanda, Carol, Paulinha, Viviane, Roberta e Mirelle pelo apoio, aprendizado e compreensão.

À minha chefe, Maria José Gilbert, pela colaboração com a escala e por todo apoio, aprendizado e compreensão.

A todos os funcionários da pediatria, pelo apoio, carinho e aprendizado.

Às minhas amigas de pós-graduação, Tainá, Maria Fernanda, Aline, Michelle Nunes, Michele Miyauti, Mariana Sanches, Maria Cristina pelo apoio, carinho, compreensão, convivência, ensinamentos, aprendizado, por compartilharem experiências em pesquisas e conhecimentos e por me guiarem na conclusão desse trabalho.

Às minhas amigas e monitoras, Daniele e Amanda, pela amizade, apoio, compreensão e pelos momentos compartilhados de ensino-aprendizado. 
A todos os meus amigos e amigas, pela escuta, amizade e compreensão dos momentos de ausência para a conclusão desse trabalho.

Ao Everson, meu cunhado, pelo apoio e colaboração para a conclusão desse trabalho

À funcionária da pós-graduação, Shirley, por toda atenção, colaboração e compreensão.

Ao José Mário, pela atenção, trabalho e disponibilidade na conclusão deste trabalho.

À Escola de Enfermagem de Ribeirão Preto da Universidade de São Paulo por manter suas portas abertas para eu continuar o meu aprendizado.

Ao Conselho Nacional de Desenvolvimento Científico e Tecnológico - CNPq, pelo apoio de infraestrutura à pesquisa. 
“Não sei... Se a vida é curta

Ou longa demais para nós,

Mas sei que nada do que vivemos Tem sentido, se não tocamos o coração das pessoas.

Muitas vezes basta ser:

Colo que acolhe, Braço que envolve, Palavra que conforta, Silêncio que respeita, Alegria que contagia, Lágrima que corre, Olhar que acaricia, Desejo que sacia, Amor que promove. E isso não é coisa de outro mundo, É o que dá sentido à vida. É o que faz com que ela Não seja nem curta, nem longa demais, Mas que seja intensa, Verdadeira, pura... Enquanto durar." (Cora Coralina) 


\section{RESUMO}

MELLO, T.B. Comunicação de más notícias: experiência de mães de crianças e adolescentes com câncer. 2013. 89 f. Dissertação (Mestrado). Escola de Enfermagem de Ribeirão Preto, Universidade de São Paulo, 2013.

Mesmo com os avanços tecnológicos, a comunicação permanece sendo uma ferramenta primária e indispensável por meio da qual profissionais de saúde e usuários trocam informações. Elementos como empatia, compreensão, interesse, desejo de ajuda e bom humor são essenciais para promover um ambiente de conforto emocional, o qual pode proporcionar ao paciente e membros da equipe de saúde melhores condições para a comunicação de notícias difíceis. Este momento pode envolver não somente a revelação do diagnóstico, como também a progressão da doença, a necessidade de procedimentos invasivos ou o encaminhamento para cuidados paliativos. O objetivo do presente estudo foi descrever a experiência de mães de crianças e adolescentes com câncer diante da comunicação de más notícias. Trata-se de um estudo de natureza descritiva e exploratória, com análise qualitativa dos dados. Participaram mães de crianças e adolescentes com câncer em acompanhamento em um hospital-escola do interior do estado de São Paulo; como instrumento de coleta de dados, optamos pelo grupo focal. A análise do material empírico ocorreu segundo o processo de análise de conteúdo do tipo temática indutiva com organização ao redor de três temas: A comunicação da má notícia, descrito com base na revelação do diagnóstico de câncer, no modo de comunicar e na compreensão diante da notícia; A revelação da notícia para a criança e adolescente, que trata da comunicação com a criança e o adolescente, os envolvidos no processo de revelação do diagnóstico, abrangendo o autocuidado e a tomada de decisão; Comunicação dos cuidados paliativos, referente à comunicação da mudança do cuidado curativo para os cuidados paliativos. Observamos que um dos aspectos em comum nos diferentes grupos focais foi o impacto da revelação do diagnóstico de câncer, associado a sentimentos de dor, sofrimento e medo da morte, no entanto, entrelaçados pela esperança da cura. Para algumas mães, o filho não deveria ter conhecimento da doença e do tratamento, nem participação ativa nesse processo, pois assim não sofreria. Por outro lado, observamos mães que destacaram o momento da comunicação, mesmo que de uma má notícia, como importante, pois contribuiria para que o filho tivesse uma melhor adesão aos cuidados e tratamento, acreditando que tal tarefa é conduzida de forma mais apropriada pelos pais com apoio da equipe de saúde. Outro ponto relevante nos resultados foi o impacto da comunicação da transferência dos cuidados curativos para paliativos, pois, diferentemente do momento da revelação do diagnóstico, a esperança do tratamento com a finalidade de cura não esteve presente. Os resultados do estudo podem contribuir para a compreensão da experiência dessas mães com vistas à produção de cuidados de saúde que atendam às reais necessidades de crianças e adolescentes com câncer e de seus pais diante da comunicação de más notícias.

Descritores: comunicação, câncer, criança, adolescentes, enfermagem, mães. 


\begin{abstract}
MELLO, T.B. Communication of bad news: experience of mothers of children and adolescents with cancer. 2013. 89 f. Thesis (Master's degree), University of São Paulo at Ribeirão Preto, College of Nursing, 2013.

Despite the advances in technology, communication remains a primary and indispensable tool through which healthcare professionals and users exchange information. Elements such as empathy, understanding, interest, desire to help and good mood are essential to promote an environment of emotional comfort, which can provide patients and members of the healthcare team with better conditions to communicate difficult news. That moment can involve not only the disclosure of the diagnosis, as well as information concerning the progression of the disease, a need for invasive procedures or a referral to palliative care. The aim of this study was to describe the experience of mothers of children and adolescents with cancer facing the communication of bad news. This descriptive and exploratory study was performed using qualitative data analysis. The participants were mothers of children and adolescents with cancer undergoing treatment at a teaching hospital in the state of São Paulo. Data collection was performed using chose the focus groups. Thematic content analysis of the empirical material was performed, and organized considering three themes: Communication of bad news, described based on the disclosure of the cancer diagnosis, how it was communicated, and how the news was understood; Revealing the news to children and adolescents, comprising the communication with children and adolescents, those involved in disclosing the diagnosis, as well as self-care and decision-making; Communication of palliative care, refers to communication the change from curative care to palliative care. It was observed that one of the common features in the different focus groups was the impact of the disclosure of the cancer diagnosis, associated with feelings of pain, suffering and fear of death, however, always entwined with the hope of healing. Some mothers preferred their child not be informed about the disease and treatment, and not participate actively in this process, because that way, her child would not suffer. On the other hand, it was observed that mothers emphasized the moment of communication as important, even when involving bad news, because it would improve their child's adherence to care and treatment, and that this task is better conducted by parents when they receive support from the health team. Patients and families referred that the communication about changing from curative to palliative care was the most difficult moment for them, because, unlike the disclosure of the diagnosis, in this case the hope of healing was not present. The results of the study can contribute to understanding the experience of these mothers with a view to producing healthcare that meets the real needs of children and adolescents with cancer and their parents facing the communication of bad news.
\end{abstract}

Keywords: communication, cancer, children, adolescents, nursing, mothers. 


\section{RESUMEN}

MELLO, T. B. Comunicación de malas noticias: experiencia de madres de niños y adolescentes con cáncer. 2013. 89 f. Disertación (Maestría). Escuela de Enfermería de Ribeirão Preto, Universidad de São Paulo, 2013.

Aún con el avance de la tecnología, la comunicación continúa siendo una herramienta primordial e indispensable, a través de la cual profesionales de salud y pacientes intercambian informaciones. Elementos como empatía, comprensión, interés, voluntad de ayudar y buen humor son esenciales para promover un ambiente de bienestar emocional, que puede proporcionarles al paciente y miembros del equipo de salud mejores condiciones para la comunicación de noticias difíciles. Dicho momento puede involucrar no sólo la comunicación del diagnóstico, sino también la progresión de la enfermedad, la necesidad de procedimientos invasivos o la derivación a cuidados paliativos. Este estudio objetiva describir la experiencia de madres de niños y adolescentes con cáncer ante la comunicación de malas noticias. Estudio de naturaleza descriptiva y exploratoria, con análisis cualitativo de los datos. Participaron madres de niños y adolescentes con cáncer, en seguimiento en un hospital-escuela del interior del Estado de São Paulo; los datos se recolectaron por vía de grupo focal. El análisis del material empírico se realizó según el proceso de análisis de contenido, de tipo temático inductivo, organizado en torno a tres temas: La comunicación de la mala noticia, descrito en base a la comunicación del diagnóstico de cáncer, al modo de transmitirla y a la comprensión ante la noticia; La comunicación de la noticia al niño y adolescente, compuesto por la comunicación con el niño y el adolescente, los involucrados en el proceso de revelación del diagnóstico, con el autocuidado y la toma de decisiones; Comunicación de cuidados paliativos, con la comunicación del cambio del cuidado curativo a los cuidados paliativos. Observamos que uno de los aspectos en común en los diferentes grupos focales fue el impacto de la revelación del diagnóstico de cáncer, asociado a sentimientos de dolor, sufrimiento y miedo a la muerte; no obstante, enlazado a la esperanza de curación. Para algunas madres, el hijo no debería tomar conocimiento de la enfermedad y su tratamiento, tampoco debería tener participación activa en tal proceso, pues así él no sufriría. Por otro lado, observamos madres que destacaron el momento de la comunicación, aunque se trate de una mala noticia, como importante; ya que ello habría de contribuir a que el hijo tuviese una mayor adhesión a los cuidados y tratamientos, y que dicha tarea es dirigida por los padres con apoyo del equipo de salud. Otro punto relevante en los resultados fue el impacto de la comunicación de la transferencia de los cuidados curativos a los paliativos, ya que, a diferencia del momento de la revelación del diagnóstico, la esperanza de curación deja de estar presente. Los resultados del estudio pueden contribuir a la comprensión de la experiencia de estas madres, apuntando a la producción de cuidados de salud que atiendan las reales necesidades de niños y adolescentes con cáncer y las de sus padres, ante la comunicación de malas noticias.

Descriptores: Comunicación; Cáncer; Niño; Adolescente; Enfermería; Madres. 


\section{LISTA DE QUADRO}

Quadro 1 - Identificação das mães e das crianças e dos adolescentes com câncer . 39

Quadro 2 - Organização do material empírico 


\section{SUMÁRIO}

APRESENTAÇÃO ......................................................................................................................13

1 INTRODUÇÃO ...........................................................................................................17

1.1 Comunicação enquanto instrumento do cuidado de saúde...................................................18

1.2 Comunicação de más notícias........................................................................................20

1.3 Particularidades de crianças e adolescentes com câncer e de suas famílias........................29

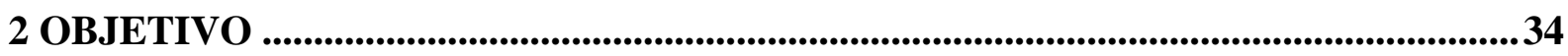

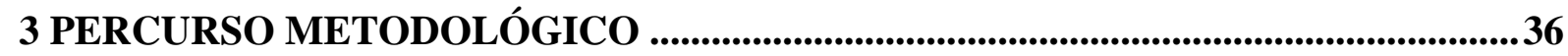

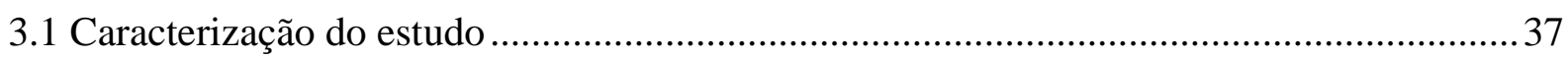

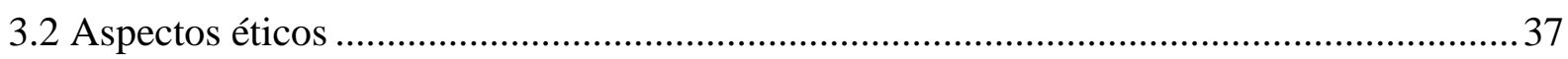

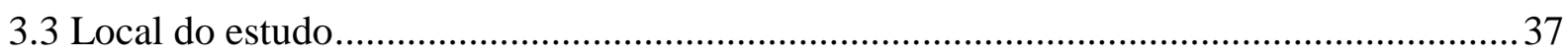

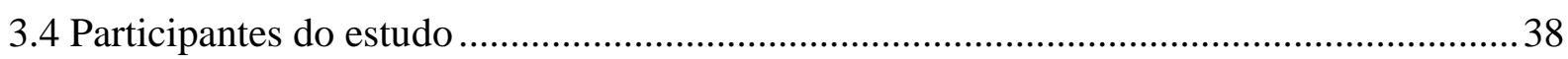

3.5 Procedimentos para coleta e registros dos dados...........................................................40

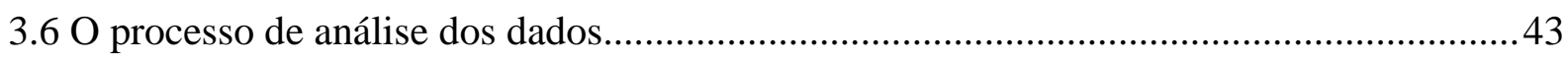

4 APRESENTAÇÃO E DISCUSSÃO DOS RESULTADOS .............................................45

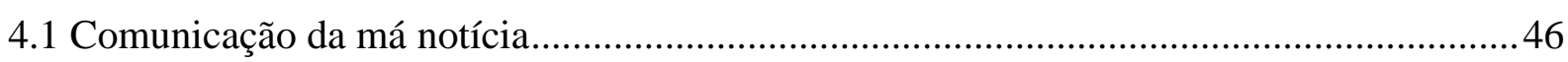

4.2 A revelação da notícia para a criança e adolescente...........................................................55

4.3 Comunicação dos cuidados paliativos .............................................................................63

5 CONSIDERAÇÕES FINAIS..................................................................................................68

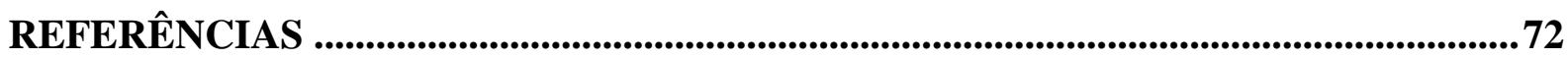

APÊNDICES

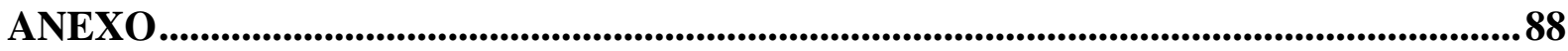


Na escolha da minha profissão fui influenciada por uma enfermeira que conheci quando minha mãe me levou para visitar um hospital, onde fui apresentada também a uma amiga dela, enfermeira e apaixonada pela profissão, pelo cuidado e pela assistência. Entusiasmada com os relatos a respeito do trabalho que desenvolviam, decidi prestar o vestibular para Enfermagem e, em 2005, ingressei na Escola de Enfermagem de Ribeirão Preto da Universidade de São Paulo (EERP - USP) no curso Bacharel em Enfermagem.

Logo ao ingressar na universidade, já sabia que trabalharia com enfermagem pediátrica, sempre com o desejo de cuidar dos pequeninos. Assim, no primeiro semestre iniciei atividades de extensão e pesquisa relacionadas à pediatria e oncologia e, no decorrer da graduação, participei dos encontros da Liga de Prevenção e Combate ao Câncer (LPCC), quando me aproximei da área de oncologia pediátrica. Tive, então, oportunidade de estudar, organizar e participar de jornadas e eventos de oncologia e oncologia pediátrica.

No segundo ano da graduação teve início o Grupo de Cuidados Paliativos de Ribeirão Preto da Universidade de São Paulo, momento em que desenvolvi meus primeiros estudos na temática e participei da organização de eventos na área, por exemplo, o "I Encontro sobre Cuidados Paliativos - Humanização da Finitude do Homem" e "II Encontro sobre Cuidados Paliativos - Desafios e Perspectivas”.

Também tive a oportunidade de participar das atividades do Grupo Cia do Riso Prescrição do Dia: Infusão de Alegria, cujo objetivo é utilizar a arte do teatro clown para a interação com crianças e adolescentes no processo de hospitalização, bem como com suas famílias. Participar desses momentos fez com que compreendesse a importância de valorizar o processo de crescimento e desenvolvimento de crianças e adolescentes durante a hospitalização.

Iniciei as atividades no campo hospitalar, na área de pediatria, no terceiro ano da faculdade, quando realmente tive a certeza de que seria a minha área de atuação como enfermeira. Assim, no último ano do curso, optei por realizar o estágio supervisionado na Clínica Pediátrica, momento em que reconheci minha vocação para o cuidado e assistência às crianças e adolescentes e suas famílias, bem como pude iniciar atividades de pesquisa na área de pediatria, especificamente na pediatria oncológica.

A articulação dessas atividades na graduação possibilitou que compreendesse o cuidado em saúde para além dos aspectos biomédicos; assim, em busca de mais conhecimentos na área e aprimoramento das habilidades cursei especialização em Enfermagem Pediátrica. 
Logo após a graduação, iniciei minhas atividades profissionais em um hospital privado da cidade de Ribeirão Preto, atuando como enfermeira na Unidade de Terapia Intensiva Neonatal e Pediátrica, onde pude confirmar o dom para cuidar das crianças e adolescentes em condição crítica e de acolher e confortar suas famílias utilizando a comunicação enquanto um dos instrumentos desse processo.

No ano seguinte fui contratada para desenvolver minhas atividades na Clínica Pediátrica do Hospital das Clínicas da Faculdade de Medicina de Ribeirão Preto da Universidade de São Paulo, onde me aproximei mais particularmente de crianças e adolescentes em situação de doença crônica, em especial daqueles com câncer. Diante desse complexo cuidado, passei a interrogar alguns comportamentos relacionados a esses pacientes e seus familiares, como a angústia, o sofrimento e o medo diante da descoberta do diagnóstico de câncer, o processo de morte e morrer, a mudança da rotina e, ao mesmo tempo, a busca por vínculos e esperança de cura.

A prática clínica direcionada a esses pequenos pacientes e seus familiares e a vontade de compreender tais questões levaram-me a buscar por uma pós-graduação e, então, ingressei no Mestrado com o objetivo de estudar e pesquisar oncologia pediátrica.

Durante o primeiro ano (2011), na condição de aluna da pós-graduação da Escola de Enfermagem de Ribeirão Preto da Universidade de São Paulo, Programa Enfermagem em Saúde Pública, cursei disciplinas que contribuíram para o aperfeiçoamento do meu projeto de pesquisa e de minha prática clínica e, no decorrer do mestrado, pude realizar, por três vezes consecutivas, o Estágio do Programa de Aperfeiçoamento do Ensino - PAE, o que considero ter contribuído para a minha formação na prática da docência. No segundo ano, em decorrência de aspectos operacionais que inviabilizaram a continuidade da proposta do projeto de pesquisa inicial, elaborei outra questão-problema, desenvolvendo um novo projeto, com uma nova introdução, objetivo e método, porém permanecendo na mesma linha de pesquisa.

Participei do grupo de pesquisa GPECCA - Grupo de Pesquisa em Enfermagem no Cuidado à Criança e ao Adolescente e tal atividade foi de suma importância para meu amadurecimento como pós-graduanda, uma vez que favoreceu o contato com docentes e alunas de pós-graduação e a troca de experiências na área da pesquisa. Também participei, como bolsista do Fundo de Cultura e Extensão Universitária, de um projeto sobre cuidados paliativos com o Grupo de Cuidados Paliativos do Hospital das Clínicas da Faculdade de Medicina de Ribeirão Preto da Universidade de São Paulo e desenvolvi atividades no Programa de Monitoria na disciplina estágio supervisionado. Essas atividades vinculadas à 
minha prática profissional ajudaram-me na elaboração do novo projeto de pesquisa, hoje concretizado nesta dissertação de mestrado, cujo objetivo é descrever a experiência de mães de crianças e adolescentes com câncer diante da comunicação de más notícias relacionadas ao diagnóstico de câncer, procedimentos e cuidados paliativos.

Para tanto, inicio apresentando aspectos da comunicação enquanto instrumento do cuidado em saúde e da comunicação de más notícias, finalizando com o objetivo. Na sequência, apresento a abordagem metodológica, seguida da discussão dos resultados.

As considerações finais sinalizam ser pertinente compreender a experiência de comunicação de más notícias com vistas à produção de cuidados em saúde que atendam às reais necessidades de crianças e adolescentes no processo saúde-doença e de seus pais. Esse conhecimento possibilita que todos possam refletir sobre a situação e desenvolver estratégias de enfrentamento e de cuidado que visem o cuidado integral. E também realça a importância das instituições formadoras investirem na capacitação de seus alunos em habilidades de comunicação e relacionamento com o paciente e familiares. 
1 INTRODUÇÃO 


\subsection{Comunicação enquanto instrumento do cuidado de saúde}

Mesmo com os avanços tecnológicos, a comunicação permanece sendo a ferramenta primária e indispensável por meio da qual profissionais de saúde e usuários trocam informações. Elementos como a empatia, compreensão, interesse, desejo de ajuda e bom humor são indispensáveis para promover um ambiente de conforto emocional, o qual pode proporcionar ao paciente e membros da equipe melhores condições para a comunicação em saúde (JACOBSEN; JACKSON, 2009).

A origem da palavra comunicar está no latim comunicare, cujo significado é por em comum. Comunicação pressupõe o entendimento das partes envolvidas; não há entendimento se não houver, anteriormente, a compreensão (SILVA, 2002). Quando nos comunicamos com as pessoas, não temos apenas o compromisso de transmitir um conteúdo, uma informação, pois toda comunicação envolve um sentimento, ou seja, o que sentimos quando estamos diante do outro e da informação que temos a transmitir (SILVA, 2006).

Se considerarmos que o conceito de comunicação pressupõe a existência de um emissor, um receptor e algo a ser comunicado entre os dois primeiros, tal processo sofre influências tanto do emissor quanto do receptor, assim como do meio que os circunda. Nem sempre o que é emitido é recebido e, quando recebido, o é da mesma forma que foi emitido. Avançando nessa questão, o que se comunica não é algo preexistente à comunicação em si, mas criado no instante da comunicação. O que se comunica é um acontecimento; é a intenção ou o desejo daquele que emite em contato com o desejo e a defesa daquele que recebe, criando um sentido próprio e sempre novo. Não há defesa estabelecida que seja tão densa e estruturada que não possa ser desmontada pela surpresa. A comunicação é um encontro (BRASIL, 2010).

O ser humano faz uso da comunicação para expressar suas ideias, transmitir conhecimentos, sentimentos, pensamentos e atitudes. É um processo que permite que ao indivíduo compartilhar sua vivência e experiência, estando em constante interação (STEFANELLI; CARVALHO, 2012).

O processo de comunicação humana envolve uma complexidade de fatores, tais como conteúdo, forma e linguagem, que se presentificam em todo momento nos processos interrelacionais. Além do aspecto da significação implícita na linguagem, a análise pragmática da comunicação nos auxilia a pensar sobre as consequências da comunicação no comportamento humano (NIEWEGLOWSKI; MORÉ, 2008). 
Toda comunicação, portanto, tem duas partes: a primeira diz respeito ao conteúdo, ao fato, à informação que queremos transmitir e, a segunda, ao que estamos sentindo quando nos comunicamos com a pessoa. O conteúdo da nossa comunicação está intimamente ligado ao nosso referencial de cultura e, nesse sentido, cabe mencionar que o profissional de saúde possui uma cultura própria, distinta daquela do leigo; portanto, torna-se importante saber que quanto mais informações possuirmos sobre aquela pessoa e quanto maior a nossa habilidade em correlacionar esse saber do outro com o nosso, melhor será o nosso desempenho no âmbito da informação e do conteúdo (SILVA, 2002, 2006).

O interessante é que nem sempre o profissional da área de saúde tem a consciência de que, ao falarmos em comunicação, não nos referimos apenas às palavras expressas para a outra pessoa, as quais são dimensionadas como comunicação verbal. Toda comunicação humana, face a face, interpessoal, também se faz pela comunicação não verbal, ou seja, de todas as formas de comunicação que não envolvem diretamente as palavras. Quando falamos de relacionamento interpessoal, a comunicação verbal sozinha não existe, pois, além dela, há de se considerar a maneira como falamos, denominada paraverbal, envolvendo silêncios e grunhidos que utilizamos ao falar, as pausas que fazemos entre as frases e palavras ou a ênfase que colocamos na voz. Além desse componente paraverbal, temos as expressões faciais, as nossas posturas corporais diante do outro, a maneira como o tocamos, as distâncias interpessoais que mantemos com essa outra pessoa (SILVA, 2006).

Segundo Ferreira (2000), a comunicação é um dos principais instrumentos do cuidado em saúde, especialmente quando dirigida a pacientes com doenças graves como o câncer. Nessa situação, comunicação e interação são processos importantes por provocarem ações e reações para o estabelecimento de uma cadeia recíproca de opiniões e comportamentos entre indivíduos e grupos.

Pinheiro (2002) argumenta que a relação entre profissionais de saúde e pacientes pode apresentar-se segundo três modelos: - modelo ativo/passivo: quando os profissionais de saúde decidem o tratamento de forma unilateral; - modelo de cooperação: quando o diagnóstico é estabelecido e as opções terapêuticas são apresentadas aos pacientes buscando as melhores soluções; - modelo de participação e consentimento mútuos: pacientes e profissionais são parceiros, cada qual com suas atribuições e responsabilidades. 


\subsection{Comunicação de más notícias}

Em oncologia, notícias difíceis podem ser transmitidas com certa frequência, dado que o diagnóstico de câncer desencadeia uma série de mudanças na vida do paciente e família. Dentre tais notícias, destacam-se, além do diagnóstico, as recidivas, as cirurgias mutiladoras, a toxicidade da quimioterapia, os efeitos adversos da radioterapia e os cuidados paliativos. Neste encontro, o médico agirá segundo seus conhecimentos, experiência clínica e capacidade de comunicação de uma notícia difícil ao paciente e seu familiar (ALMANZA-MUÑOS; HOLLAND, 1999; DOYLE; O’CONNEL, 1996; VANDEKIEFT, 2001).

A dificuldade e a frequência com que ocorrem esses eventos contrastam com o preparo deficiente das equipes de saúde em termos de habilidades gerais de comunicação, principalmente na maneira de informar resultados negativos no curso da evolução de uma doença (ALMANZA-MUÑOS; HOLLAND, 1999). Na prática médica, não são incomuns as queixas de pacientes e familiares que receberam más notícias sobre sua saúde de maneira inadequada e nunca mais esqueceram esse infeliz momento.

Transmitir uma má notícia é uma atividade extremamente complexa e exige preparo e sensibilidade do profissional de saúde. Esse processo de comunicação esteve, por muito tempo, sob foco de atenção de diversos estudiosos; no entanto, foi somente nos últimos dez anos que o debate avançou. O interesse nessa forma específica de comunicação surgiu em decorrência de importantes implicações de natureza psicológica, física e interpessoal que podem levar a inúmeros conflitos, afetar os sintomas, o comportamento, os relacionamentos sociais, o prognóstico e a autopercepção do paciente (SILVA; ZAGO, 2005).

Má notícia pode ser compreendida como aquela que altera drástica e negativamente a perspectiva do paciente em relação ao seu futuro (LIMA, 2003; MULLER, 2002; VANDEKIEFT, 2001), ou seja, "qualquer informação que afeta seriamente e de forma adversa a visão de um indivíduo sobre seu futuro” (BUCKMAN, 2005). Segundo Ayarra e Lizarraga (2001), é difícil buscar uma definição que reflita todas as situações que possam implicar más notícias. Geralmente, os profissionais de saúde tendem a valorizar o que lhes parece ser mais importante; entretanto, quem deve decidir o que é ou não uma má notícia é a pessoa por ela afetada.

A forma pela qual a má notícia é apresentada pode interferir na compreensão dos pacientes sobre ela e no seu ajustamento à mesma, assim como a sua satisfação com seu médico. Os fatores mais importantes para os pacientes quando do recebimento de más notícias 
são as competências do médico, sua honestidade e atenção, o tempo e o uso de um linguajar claro (VICTORINO, 2007). Por isso, esse é um momento sempre crucial porque alterará radicalmente a perspectiva da pessoa sobre seu próprio futuro; desse modo, tanto os aspectos científicos quanto os humanísticos precisam ser conhecidos e considerados por quem realiza a comunicação (BONAMIGO; DESTEFANI, 2010).

Neste processo de comunicação, é o profissional quem primeiro recebe a má notícia, cabendo-lhe a árdua tarefa de comunicá-la aos pacientes e familiares, em meio a uma agenda sobrecarregada, em um espaço pouco propício ao acolhimento e à privacidade (BRASIL, 2010). Os principais protagonistas das más notícias são os prestadores de cuidados em saúde, notadamente os médicos, os quais, além de planejarem e gerirem esses momentos, também têm que administrar seus próprios medos e estarem preparados para aceitar as hostilidades do paciente e de seus familiares (PEREIRA, 2005). Assim, as notícias difíceis não são dirigidas somente a pacientes e familiares, pois os profissionais de saúde são os primeiros destinatários.

O processo de comunicação do prognóstico para pessoas portadoras de doenças que limitam a vida é essencial para que, em conjunto com suas famílias, possam se organizar para a tomada de decisão e planejar os cuidados de final de vida. Apesar das inúmeras razões para a comunicação do prognóstico, os profissionais de saúde, por viverem o desconforto da incerteza do prognóstico, pouco utilizam esse momento do cuidado em saúde. Esse desconforto e a cultura do "otimismo ritualizado" na medicina estão entre os fatores limitantes para comunicações de prognóstico (GRAMLING et al., 2013).

A comunicação de más notícias ao paciente pode ocorrer de forma adequada, auxiliando que aceitem a situação desfavorável, ou inadequada, o que pode gerar confusão, sofrimento e ressentimento. A revelação de uma verdade desfavorável, quando realizada com habilidade e sensibilidade, reduz consideravelmente o impacto negativo da informação sobre o paciente e familiar (NUÑEZ, 2006).

A transmissão de uma notícia difícil é uma experiência que começa por ouvir os próprios sentimentos de modo a perceber seus limites e poderes, para, então, lidar com as emoções desencadeadas por essa comunicação. Pesquisas revelam que o preparo para uma comunicação desse tipo deve iniciar pelo desenvolvimento da capacidade de ouvir e fazer contato com a experiência singular do outro; é preciso valorizar e aprimorar a capacidade de empatizar com aquele que sofre e pede ajuda, disponibilizando-se a ouvi-lo para, em seguida, avaliar até onde ele necessita saber (BRASIL, 2010).

A arte da comunicação de más notícias exige aprendizagem. A literatura apresenta inúmeras estratégias para comunicar más notícias ao paciente. No estudo de revisão realizado 
por Bonamigo e Destefani (2010), os autores destacam trabalhos que utilizam, como estratégia de comunicação, a dramatização, role player, pacientes simulados (simulated patients), pacientes padronizados (standardized patients) e também workshop; porém, o protocolo SPIKES merece especial menção (BUCKMAN, 2005).

O SPIKES constitui um guia inicialmente elaborado para pacientes portadores de câncer, mas que pode ser aplicado a outras situações. Embora apresente outras subdivisões, o protocolo pode ser sintetizado em seis passos fundamentais, que formam a palavra SPIKES: $S$ - Setting; P - Perception; I - Invitation; K - Knowledge; E - Emotions e S - Strategy and Summary. Nem toda comunicação de más notícias demandará a utilização dos seis passos, porém, quando necessário, o uso da sequência é imprescindível (BAILE et al., 2000).

$1^{\circ}$ Passo - S-Setting: preparando a entrevista. São indicados procedimentos básicos para iniciar a comunicação. Aspectos operacionais, como escolher um local privativo, sentar com o paciente e seus familiares e evitar ser interrompido, são enfatizados. Importante também rever antecipadamente os detalhes da história clínica do paciente e o resultado de seus exames; confirmar o diagnóstico, além de preparar mentalmente o que se tem a dizer, especialmente sobre como pretende responder às emoções e às perguntas difíceis do paciente e verificar previamente se ele deseja a companhia de alguma pessoa. Há indicação de se fazer uso do humor, pois ele pode reduzir a tensão e a ansiedade, bem utilizar o contato "olho a olho" e o toque, caso o paciente se mostre receptivo.

$2^{\circ}$ Passo - P-Perception: descobrindo o que o paciente sabe. O lema principal dessa etapa expressa o axioma chave do protocolo: “Antes de falar, pergunte”. Aqui é sugerido ao médico, antes de fornecer as informações médicas, a utilização de perguntas amplas, de forma a propiciar um ambiente de razoável precisão a respeito de como o paciente percebe sua situação. É importante que o médico possa avaliar o que o paciente está entendendo, corrigir possíveis informações errôneas, observar se está ocorrendo algum tipo de negação da doença e expectativas irreais quanto ao tratamento. Deve-se aproveitar esse momento para avaliar também o nível cultural do paciente com base em seu vocabulário. Deve-se ainda pesar a carga emocional de suas palavras para avaliar o que o paciente não deseja falar. Convém fixar-se na linguagem não verbal do paciente: postura, expressão facial, tom de voz, aspecto físico, dentre outros.

$3^{\circ}$ Passo - I-Invitation: identificando o quanto o paciente quer saber. Enquanto a maioria dos pacientes expressa explicitamente o interesse por informações, outros podem não agir da mesma forma, o que faz com que o médico, especialmente nesse momento, se empenhe em identificar o desejo do paciente. É importante perceber o que se deseja saber, bem como quer 
receber as informações. Os autores recomendam perguntas do tipo: "Como gostaria que eu informasse os resultados dos exames?” ou “Prefere gastar mais tempo discutindo o plano de tratamento?”. Há pacientes que não querem muitos detalhes sobre sua situação. Evitar informações, especialmente quando a doença se torna mais severa, é um mecanismo psicológico comumente manifesto. Nesse caso, a indicação é que o médico possa oferecer resposta para qualquer pergunta que possa surgir no futuro, ou fale a um parente ou amigo.

$4^{\circ}$ Passo - K-Knowledge: fornecendo conhecimento e informação ao paciente. Advertir o paciente de que más notícias estão por vir pode reduzir o choque diante da revelação. Nessa etapa em que as informações serão fornecidas, é necessária atenção para o uso do vocabulário, que deve ser adequado ao nível de compreensão do paciente, evitando também o uso de palavras técnicas. O profissional deve ainda evitar ser excessivamente direto, buscando sempre oferecer as informações paulatinamente e checando o entendimento do paciente. Nos casos em que não há um bom prognóstico, deve-se evitar falar que já não há mais o que fazer. $5^{\circ}$ Passo - E-Emotions: respondendo às emoções do paciente. É um dos mais difíceis desafios na revelação de más notícias. Inicialmente, as reações são de choque, isolamento e mágoa, podendo se manifestar pelo silêncio, choro ou raiva.

$6^{\circ}$ Passo - S-Strategy and Summary: estratégia e resumo. Nesta etapa, as responsabilidades na tomada de decisões devem ser compartilhadas, reduzindo para o médico a sensação de fracasso quando o tratamento não apresentou resultados satisfatórios. Pacientes com um plano bem esclarecido para o futuro tendem a apresentar menos ansiedade e incertezas e, nesse sentido, devem ser checados possíveis mal-entendidos por parte do paciente, avaliando se ele não está superestimando a proposta e a eficácia do tratamento definido. Ainda nessa ocasião, vale escutar os medos e as preocupações do paciente, assegurando-lhe o melhor tratamento possível.

Segundo Geovanini (2011), o momento da comunicação do diagnóstico pode representar o início de uma série de mudanças na vida do paciente e de sua família e, portanto, tem sido considerado um dos mais difíceis da prática médica. Entre os principais fatores responsáveis por tamanha dificuldade, podemos incluir a falta de preparo para o desenvolvimento dessa habilidade nos currículos das escolas médicas, a angústia e o temor da morte, inerentes à condição humana, especialmente presentes entre os profissionais de saúde.

No âmbito da prática médica, o câncer é uma das doenças que mais evocam sofrimento, seja ele físico ou emocional. A delicada tarefa de transmitir o diagnóstico de câncer faz com que o mensageiro não saia ileso desse processo, remetendo-o à sua própria finitude (TORRES, 2000). 
Segundo Diaz (2006), a comunicação de más notícias é algo estressante considerando a crença generalizada de que a revelação de um diagnóstico sombrio afeta negativamente a evolução do paciente ou sua colaboração com o plano terapêutico; surge o medo de enfrentar as reações emocionais do paciente e emergem as perguntas incômodas, levando o profissional a reconhecer seu pouco treinamento e habilidade para essa experiência.

No caso da comunicação com crianças e suas famílias, o processo também é complexo: envolve a tríade médico-pais-criança e outros membros familiares; é influenciada pelo estadio de desenvolvimento e de cognição da criança; inclui a dinâmica de interação dentro da família e distintas necessidades de pais e filhos. Por esperarmos dos mais jovens sobretudo boas notícias, a pediatria torna-se uma especialidade em que as más notícias podem produzir danos importantes à criança e à família, sendo necessário melhor compreender de que forma é possível diminuir, na prática clínica, o estresse associado a desfechos negativos nas idades mais jovens (CARRAPA, 2010).

Em pediatria, apesar de existirem estudos sobre o grau de satisfação dos pais em relação à forma como as más notícias foram transmitidas, a produção do conhecimento no que se refere às preocupações e dificuldades dos pediatras a esse respeito é reduzida. Assim, o estudo realizado por Rider, Volkan, Hafler (2008) teve por objetivo analisar as atitudes dos residentes em pediatria sobre as habilidades em comunicação e as suas percepções no que diz respeito à importância de aprendizagem de habilidades específicas em comunicação. Foi utilizado um questionário contendo 47 itens, respondido por 104 residentes em pediatria de um hospital universitário dos Estados Unidos da América. O estudo evidenciou que 90\% dos participantes concordaram que aprender a se comunicar de forma eficaz com os pacientes foi uma prioridade e 100\% concordaram ser importante demonstrar empatia e carinho, bem como ensinar estudantes de medicina a se comunicarem de forma eficaz com os pacientes. Os residentes de pediatria também consideraram importante aprender estratégias de comunicar e a maioria deles relatou confiança em competências de comunicação como entrevistas, escuta, construção de relacionamento. Entretanto, menos da metade relatou sentir-se confiante no que se refere a habilidades mais avançadas de comunicação, tais como capacidade de discutir questões de término de vida, falando com crianças sobre a doença grave, transmitindo más notícias, lidando com a difícil relação paciente/pais

A dificuldade de comunicação da equipe de saúde com famílias também se relaciona com o fato de que, para o médico, a morte do paciente simboliza o fracasso profissional. Assim, à medida que a criança vai apresentando piora no seu estado de saúde, há uma crescente dificuldade de estabelecer a comunicação com a família. Nieweglowski e Moré 
(2008) realizaram um estudo de caráter descritivo e exploratório, por meio de análise qualitativa dos dados, utilizando como instrumento para coleta de dados a entrevista semiestruturada, com a participação de oito famílias de crianças internadas na Unidade de Terapia Intensiva Pediátrica. Os dados foram estudados com base na análise de conteúdo de 4 unidades temáticas: comunicando diagnósticos e procedimentos, as expectativas na comunicação equipe-família, a comunicação e a sustentação das interações hierárquicas e de submissão e a comunicação e o processo de metacomunicação equipe-família. O estudo obteve resultados como a presença de uma trama comunicacional no processo de comunicação entre equipe de saúde e família, que, por sua vez, teve repercussão direta na qualidade do trabalho dos profissionais e no maior ou menor sofrimento emocional da família. Evidenciou também a necessidade da equipe estar atenta à congruência entre a mensagem digital e a analógica devido ao fato da família estar sempre atenta às pistas comunicacionais. Observou-se, ainda, que a metacomunicação esteve presente nas comunicações da equipe, aumentando o estresse familiar, assim como mensagens com dupla vinculação, gerando desconfirmação das informações e desconcerto nas famílias.

Uma análise da perspectiva dos pais e cuidadores sobre as competências de comunicação que devem ser ensinadas aos estudantes de medicina sinalizou para os aspectos relacionais e humanísticos da comunicação: demonstrar respeito pelo indivíduo, não ter preconceitos ou comportar-se de modo paternalista, compreender os efeitos do estresse e da ansiedade nos doentes e famílias (HAMMOND; MCLEAN, 2009).

Perosa e Ranzani (2008) realizaram um estudo transversal, cujo objetivo foi avaliar como os médicos de um hospital-escola que atendiam crianças em ambulatório, prontosocorro, enfermaria e UTI pediátrica, posicionavam-se quanto a comunicar à criança uma má noticia; os autores utilizaram um questionário semiestruturado como instrumento de coleta de dados, que na primeira parte visava descrever o perfil sociodemográfico dos médicos; a segunda compreendia um conjunto de questões abertas e fechadas que versavam sobre o conceito de má notícia para a criança, a necessidade de comunicá-la, se o médico precisava enfrentar essa situação e como havia se capacitado para tal. Os resultados revelaram que a maioria dos médicos entrevistados definiu má notícia como a revelação de um diagnóstico ou prognóstico ruim e reconheceu, de forma quase unânime, que a criança deve ser posta a par do seu estado de saúde e dos procedimentos aos quais será submetida. Observou-se que foi polêmica a definição do que é uma má notícia, assim como a questão de como a criança deve ser informada. O estudo também demonstrou que a maioria dos médicos não recebeu ensinamentos específicos em sua formação para a comunicação de má notícia, porém uma 
parcela daqueles formados mais recentemente, em oposição aos formados há mais tempo, disse ter recebido ensinamentos específicos e treinamento na graduação para transmitir más notícias à criança. Todos os participantes da pesquisa consideraram importante contemplar tópicos referentes à comunicação de más notícias no currículo médico. Os sujeitos foram unânimes em afirmar que, antes de informar a criança, é preciso notificar os pais ou responsáveis.

Para os autores acima mencionados, a comunicação direta com a criança não é usual, ou seja, a criança tem tido pouca participação nesse processo. Argumentam que nas consultas de rotinas e hospitalizações, os médicos até solicitam que descrevam os sintomas, mas tendem a excluí-la das informações referentes ao diagnóstico e tratamento, dirigindo-se principalmente aos pais, possivelmente pela dificuldade de abordar crianças e adolescentes, acreditando que esses já compreenderam as informações fornecidas pela equipe de saúde.

Estudos (PANTELL et al., 1982; PEROSA; RANZANI, 2008; TATES et al., 2002) identificaram que a comunicação direta entre o profissional e a criança, principalmente quando portadora de doença crônica, contribuiu para melhor adesão ao tratamento e aumentou a satisfação com o atendimento, proporcionando consequente melhora do prognóstico.

No encontro entre médicos, pacientes e familiares, além das condutas técnicas, aspectos pessoais de cada um entram em cena, determinando a singularidade das relações. Trata-se de um aspecto que se insere no campo dos relacionamentos humanos, onde os precedentes teórico-práticos podem auxiliar, porém nunca determinar uma padronização de comportamento (GEOVANINI, 2011).

Em estudo conduzido por Carrapa (2010), em grande parte dos casos, as famílias relatavam um elevado estresse quando eram comunicadas sobre más notícias sem compaixão ou quando os membros da equipe se comportavam de um modo pouco sensível. Tanto os membros da equipe quanto os pais enfatizaram a existência de suporte emocional e social como algo positivo em contextos dessa natureza, notadamente na esfera de cuidados paliativos pediátricos. As preferências dos pais sobre o modo como desejariam receber as más notícias incluem: clareza, detalhes e certeza, salientando as características positivas da criança; informação específica sobre especialidades de referência, serviços e apoio e a comunicação realizada por um profissional que lhes seja familiar.

Esse mesmo estudo (CARRAPA, 2010) identificou que, para a maioria dos pais, os filhos não deveriam estar presentes nos momentos de relatos de más notícias, sendo necessário que primeiramente possam se recompor para, então, poderem reconfortar as crianças e conseguirem lidar com as suas reações. Por outro lado, se algumas crianças 
preferem que sejam os pais os primeiros a receber as notícias, outras também gostariam de estar presentes; para outras, seria ainda indiferente. Muitas vezes, as crianças não necessitam de muitas informações; apenas gostariam que os médicos estivessem disponíveis para responder a questões simples, por eles consideradas pouco relevantes, mas, por elas, de grande importância.

É importante buscar um espaço físico adequado para a revelação de uma má notícia, sendo conveniente evitar corredores e espaços divididos, optando por uma sala mais privativa para a comunicação. É preferível ainda informar pessoalmente, uma vez que não podemos prever a resposta emocional do paciente e de seus familiares. Importante também que o paciente esteja acompanhado quando for informado; caso contrário, é melhor esperar a chegada de algum familiar (AYARRA; LIZARRAGA, 2001).

O Ministério da Saúde, o Instituto Nacional do Câncer - INCA e o Hospital Israelita Albert Einstein elaboraram, em conjunto, um projeto que tem por objetivo qualificar profissionais de saúde, especialmente médicos, para a melhoria do acolhimento, da comunicação e do vínculo terapêutico com os pacientes na rede hospitalar pública da cidade do Rio de Janeiro. Tal projeto também tem a finalidade de divulgar e ampliar o uso de tecnologias inovadoras para o desenvolvimento de habilidades relacionais e comunicacionais que qualifiquem e humanizem a atenção e a gestão compartilhada da clínica no Sistema Único de Saúde - SUS e capacitar profissionais de saúde para a escuta e o manejo de situações difíceis na comunicação com os pacientes (BRASIL, 2010).

Assim, o livro “Comunicação de notícias difíceis: compartilhando desafios na atenção à saúde”, lançado em 2010 pelo Instituto Nacional de Câncer, é resultado dessa experiência inovadora que reúne grupos interdisciplinares de profissionais para discussão de casos clínicos, baseados na formulação de Michel Balint, tendo como tema central as dificuldades de comunicação de más notícias na prática clínica dos profissionais da saúde. Esse programa abrange a rede de hospitais federais e universitários da cidade do Rio de Janeiro e é parte integrante das ações do HumanizaSUS, a Política Nacional de Humanização cujo objetivo é efetivar os princípios do Sistema Único de Saúde. A metodologia do projeto envolveu grupos multiprofissionais de trabalho, legitimando a criação de um espaço para troca de experiências entre os profissionais em relação às dificuldades cotidianas enfrentadas ao lidar com formas graves de adoecimento. Essa metodologia foi desenvolvida com o intuito de responder à demanda de produção de conhecimentos nessa área, resultando em um laboratório de práticas para beneficiar diretamente os profissionais envolvidos. Foram 109 participantes, dos quais 54 médicos, 21 enfermeiros, 15 psicólogos, 13 assistentes sociais, 4 fisioterapeutas e 2 
nutricionistas, tanto do INCA quanto de serviços de oncologia de hospitais federais, hospitais universitários e institutos de ensino da rede de atenção oncológica e de cuidados paliativos do Rio de Janeiro (BRASIL, 2010).

Como recorte estratégico inicial, foi selecionada a rede hospitalar de atenção oncológica da cidade do Rio de Janeiro, privilegiando as patologias prevalentes do câncer (de colo de útero e de mama), as quais também são priorizadas pelas metas do programa Mais Saúde e pelos Pactos pela Saúde e pela Vida do Ministério da Saúde. Foram ainda incluídos no recorte a oncologia pediátrica e os cuidados paliativos em virtude dos desafios que lançam ao processo de cuidado na rede SUS (BRASIL, 2010).

Atualmente ainda se discute a quem cabe a responsabilidade pela comunicação de má notícia aos pacientes e familiares. Muitos estudiosos argumentam ser atribuição do profissional médico. Entretanto, em estudo realizado por González (2010), a discussão é no sentido de que a comunicação de má notícia é um processo que envolve diferentes profissionais de saúde, não apenas o médico e o paciente, mas, em muitos casos, os enfermeiros e familiares. O papel da enfermagem, especialmente dos enfermeiros, é importante antes, durante e após o processo, uma vez que esse profissional permanece mais tempo junto ao paciente. Assim, esse processo, quando realizado pelo conjunto dos profissionais de saúde, enriquece o processo de cuidar no momento da comunicação.

Para Pereira (2005), é imprescindível o desenvolvimento de habilidades comunicacionais entre os profissionais de saúde, as quais possibilitam o desencadeamento de relações interpessoais com qualidade. Essas relações fazem parte do cotidiano dos profissionais de saúde, numa relação com pessoas carentes de alguém que cuide e trate, ou seja, satisfaça suas necessidades. Quando atendemos às necessidades dos outros, temos que nos basear no fato de que ambos, paciente e profissional de saúde, possuem valores e crenças diferenciadas que devem ser considerados e respeitados.

Assim, a comunicação de uma má notícia marca o início de uma série de mudanças negativas na vida das famílias, das crianças e dos adolescentes. A qualidade de comunicação entre paciente e profissional está relacionada ao ajuste emocional à doença e ao envolvimento do paciente e seus familiares no tratamento, necessitando ser valorizada. A conduta dos profissionais deve pautar-se nos valores humanos e não apenas nos aspectos técnicos e terapêuticos.

Há uma crescente preocupação com a comunicação e com os cuidados centrados na criança e adolescente com condição crônica e na família. Apesar dos constrangimentos inerentes à transmissão de informações difíceis aos pais e a crianças e adolescentes pelos 
médicos, sabe-se que para a qualidade dos cuidados e satisfação dos doentes é importante realizar essa comunicação de forma empática, contemplando as características e preferências dos pais e dos filhos, sobre as quais pouco se sabe, havendo ainda necessidade de investigações no sentido de conhecê-las. Alguns dados sinalizam que esses pequenos cidadãos ainda se sentem excluídos das consultas e que a maioria deles aprecia a oportunidade de estar presente com os seus pais quando são reveladas más notícias acerca do seu estado de saúde. Gostariam também de ter um papel ativo nos processos de decisão visto que, por vezes, suas preferências não são as mesmas de seus pais, tornando necessário que o profissional de saúde saiba gerir esse conflito (CARRAPA, 2010).

Para tanto, são indispensáveis mudanças na postura dos profissionais no cotidiano da assistência e na sua formação de forma a estarem capacitados para enfrentar situações de cuidado a crianças e adolescentes com câncer e a seus familiares nas quais a comunicação de más notícias pode ser frequente.

\subsection{Particularidades de crianças e adolescentes com câncer e de suas famílias}

O crescente desenvolvimento tecnológico em saúde nas últimas décadas vem aumentando a expectativa de vida da população, ampliando a sobrevida em muitos casos anteriormente sem possibilidades de cura. Particularmente no que se refere à mudança do perfil epidemiológico de crianças e adolescentes no Brasil, com aumento da prevalência de condições crônicas nessa população, torna-se de fundamental importância a habilidade em comunicar más notícias, uma vez que apresentar o diagnóstico de uma doença crônica, como o câncer, para pais e filhos, não é uma tarefa fácil para quem a realiza e precisa nesse momento estar preparado para também acolher e confortar as pessoas (DRUCKER, 2007).

Segundo a Organização Mundial de Saúde (2002), até metade do século XX, as principais causas de morbidade e de mortalidade no âmbito mundial eram as doenças de origem infecciosa. A partir de então, observa-se um maior número de doenças crônicas, muitas delas gerando incapacidades ou mesmo mortes. Embora muitas vezes associadas ao processo de envelhecimento, elas ocorrem em todas as idades, havendo, inclusive, algumas típicas da infância e da adolescência.

De acordo com o Ministério da Saúde (2011a), as condições crônicas com maior repercussão na saúde são as doenças cardiovasculares, o diabetes mellitus, o câncer e as 
doenças respiratórias crônicas. Em pediatria, a discussão da condição crônica tem sido associada mais frequentemente ao câncer, diabetes mellitus, fibrose cística, problemas neurológicos e doenças respiratórias como a asma (RIBEIRO; ROCHA, 2007).

Na presente investigação, nossa proposta é compreender a experiência de mães de crianças e adolescentes com câncer diante da comunicação de más notícias referentes ao diagnóstico, procedimentos invasivos e cuidados paliativos.

O câncer é caracterizado por uma proliferação desordenada e descontrolada de células anormais, causando comprometimento de tecidos e órgãos (BRASIL, 2012); é uma patologia preocupante para o sistema de saúde uma vez que a economia se desenvolve, o estilo de vida se moderniza e a expectativa de vida aumenta. É considerado um problema de saúde pública mundial por suas altas taxas de incidência e mortalidade (BRASIL, 2011b).

Trata-se de uma enfermidade rara em crianças e adolescentes, na comparação com casos de adultos, correspondendo a cerca de 2 a 3\% do total de neoplasias no país (BRASIL, 2008). No entanto, apesar de sua baixa freqüência, tem grande impacto (VILLARROEL, 2006) na vida do indivíduo e de sua família, afetando dimensões biológicas, sociais, emocionais, afetivas, existenciais e culturais (LIMA, 2002).

O câncer infanto-juvenil não deve ser considerado uma doença simples, mas uma gama de diferentes malignidades, por variar de acordo com o tipo histológico, localização primária do tumor, etnia e sexo (BRASIL, 2008). Com relação à idade, pode ocorrer em qualquer idade, incluindo recém-nascidos, crianças e adolescentes (ALMARAZ, 2007).

Quando observamos os indicadores epidemiológicos no contexto da saúde da criança e do adolescente, ele adquire contornos de gravidade por se constituir na primeira causa de morte por doença na faixa etária de cinco a 19 anos, quando excluídas as causas externas, como acidentes e violência (BRASIL, 2008). No município e estado de São Paulo, é também a primeira causa de óbito entre cinco e 14 anos de idade, excluindo-se as causas externas (RODRIGUES; CAMARGO, 2003). Para 2012, foram estimados 384.340 casos novos de câncer, sendo 11.530 em crianças e adolescentes até 19 anos (BRASIL, 2011b).

Diferentemente do que ocorre em adultos, na maioria das vezes o câncer em crianças e adolescentes afeta as células do sistema sanguíneo e os tecidos de sustentação. Dados mundiais indicam que dentre os tipos de neoplasias que atingem essa clientela, as leucemias são as mais frequente, principalmente a leucemia linfoide aguda, seguida de tumores do sistema nervoso central, linfoma, neuroblastoma, tumor de Wilms, retinoblastoma, tumores germinativos, osteossarcoma e sarcoma; tais dados também expressam a situação da distribuição do câncer em crianças e adolescentes brasileiros (WHO, 2012; BRASIL, 2011). 
A incidência do câncer infantil tem aumentado em torno de 1\% ao ano (RODRIGUES; CAVACAMI, 2004), contudo a mortalidade tem diminuído (BRASIL, 2008); estima-se que a taxa de cura no Brasil tenha atingido índices semelhantes aos de países desenvolvidos, onde aproximadamente $70 \%$ das crianças acometidas podem ser curadas se o diagnóstico for precoce e a doença adequadamente tratada em centros especializados (WHO, 2012). Para alguns tumores, as taxas de cura são tão altas que os estudos buscam evidências para reduzir os efeitos secundários da terapêutica, em vez de unicamente aumentar a sobrevida (HOWARD; WILIMAS, 2005). Outros fatores, além do diagnóstico precoce, têm contribuído para aumentar as taxas de sobrevida como a evolução do tratamento, a descoberta de novas drogas, técnicas cirúrgicas e radioterápicas dirigidas à célula tumoral e o suporte oferecido a esses pacientes (ANDREA, 2008); destaca-se também a formação de equipes multidisciplinares especializadas e grupos cooperativos.

A sobrevida depende ainda da localização do tumor, da histologia, de sua biologia e do estado da doença no momento do diagnóstico; pacientes que desenvolvem a doença de forma localizada têm melhor prognóstico do que aqueles com patologia em estágio avançado (RODRIGUES, 2002). No entanto, a cura nem sempre é possível, principalmente quando o diagnóstico ocorre já em fase avançada da doença (CAVICCHIOLI; MENOSSI; LIMA, 2007).

Muitas das manifestações clínicas oncológicas iniciais são quase silenciosas, confundem-se e assemelham-se a sinais e sintomas de doenças comuns da infância, uma vez que são inespecíficas, dificultando o diagnóstico em crianças e adolescentes (CAMARGO; LOPES, 2000). Os sinais mais frequentes são perda de peso, diarreia, dores articulares, anorexia, febre de origem indeterminada, sudorese, dor óssea, diminuição da atividade física e mudança de humor (RODRIGUES; CAVACAMI, 2004). Febre é a queixa principal em 30\% dos casos, levando os pais a procurarem o pediatra; entretanto, aproximadamente $50 \%$ dos casos envolvem febre como um dos sintomas (VAN der JAGT, 1997). As crianças e adolescentes podem apresentar ainda sinais e sintomas interligados ao tipo de tumor; por exemplo, nas leucemias pode haver maior suscetibilidade a infecções decorrentes da invasão da medula óssea pelas células tumorais, palidez, sangramento e dor óssea; no tumor de sistema nervos central, cefaleia, vômitos, alterações motoras e cognitivas, e paralisia de nervos; massa abdominal, nos tumores de Wilms e neuroblastomas; no retinoblastoma, o embraquecimento da pupila à luminosidade, fotofobia e estrabismo e, no osteossarcoma, formação de massa e dor nos membros (BRASIL, 2012). Assim, o processo diagnóstico inicia-se com o reconhecimento dos sinais e sintomas pelos pais (LIMA, 2009) e, quando 
firmado, muitas vezes a doença já está em fase avançada. São comuns os registros de diagnósticos realizados durante exames de rotina, isso pela inespecificidade dos sinais e sintomas, como já mencionado, e pelo seu caráter insidioso.

Nas últimas décadas houve um notável progresso no tratamento do câncer em crianças e adolescentes, no decorrer do qual eles vivenciam sentimentos de ansiedade, desconforto, medo e dor. As modalidades terapêuticas são amplas, incluindo quimioterapia, cirurgias, radioterapias, imunoterapia e hormonioterapia (BRASIL, 2012). A quimioterapia é a terapêutica mais utilizada no câncer infanto-juvenil (BONASSA, 2012) e seus efeitos colaterais são entendidos pelas crianças e adolescentes com câncer sob dois aspectos: enquanto processo de sofrimento e possibilidade de cura (CICOGNA, NASCIMENTO, LIMA, 2010).

Em geral, crianças e adolescentes com câncer, bem como suas famílias, têm seu cotidiano modificado. No caso dos primeiros, surgem limitações físicas decorrentes dos sinais e sintomas da doença e podem ser frequentemente submetidos à hospitalização, a qual permeia seus processos de crescimento e desenvolvimento, modificando o cotidiano e separando-os do convívio de seus familiares, amigos e ambiente (NÓBREGA, R.D et al., 2010; VIEIRA; LIMA, 2002).

O itinerário diagnóstico e terapêutico inclui uma série de procedimentos como punções para coleta de exames de sangue ou lombar, radiografias, tomografias, ressonâncias magnéticas, dentre outros. Para Valle e Ramalho (2008), pais e filhos participam mais ativamente do tratamento e são mais colaborativos quando adequadamente informados.

O impacto do câncer na vida dessas pessoas é amplo e diverso. Sua participação em atividades e oportunidades evolutivas pode ser afetada; é possível, por exemplo, que tenham que faltar às aulas. Também apresentam maior risco de desenvolver problemas de comportamento e emocional (WONG, 2006).

A revelação do diagnóstico de câncer implica vivenciar situações marcadas pela insegurança, perigo, sofrimento e dor e, no caso do câncer pediátrico, essa revelação desdobra-se em dois momentos para as mães: o do alívio em saber o diagnóstico de seu filho e do temor mesclado à sensação de que o médico sela o seu destino e o de seu filho com a sua palavra. Em muitos casos, percebe-se que receber o diagnóstico de câncer é como receber uma sentença de morte em decorrência do grande peso dessa palavra (MALTA et al., 2009).

Segundo Valle e Ramalho (2008), cada vez mais há consenso entre os membros da equipe de saúde de que a revelação do diagnóstico deva ser feita conjuntamente para os pais e crianças e adolescentes, respeitando suas etapas cognitivas. Esse é um momento de utilizar 
palavras simples e informativas que possam ser compreendidas por uma família em desespero. Para exemplificar, mencionam ser necessário dizer as partes do corpo afetadas, explicar como se chegou ao diagnóstico, mencionar os tipos de tratamento e a duração, o prognóstico e a reabilitação.

Mesmo com os avanços no processo diagnóstico e terapêutico em oncologia pediátrica, algumas vezes observa-se a incurabilidade do câncer e, nesses casos, o foco reside nos cuidados paliativos.

Pelo exposto, observa-se que o câncer não atinge somente a criança e o adolescente. Afeta também sua estrutura familiar e social. As modificações e as adaptações são necessárias para todos os membros da família, os quais precisam aprender novas estratégias de organizar o cotidiano da criança e do adolescente, de forma mais próxima possível da normalidade; entretanto, essa nova normalidade passa a ser adaptada às condições limitantes impostas pela doença. Conforme a criança vai crescendo e se desenvolvendo, a família necessita desenvolver habilidades no seu relacionamento com ela, pois, mesmo tendo uma doença grave, precisa conviver socialmente.

Pelas implicações do ponto de vista emocional, físico e prático, Cecchetto (1999) considera tal doença como sendo da família, envolvendo, em geral, pelo menos seu núcleo interno, quando não toda a família, em sentimentos de insegurança e medo frente ao desconhecimento da situação. Esse autor argumenta que os efeitos da doença atingem a todos, ainda que com manifestações distintas em termos de conteúdo e intensidade.

É por todo esse contexto que falar de câncer, de mutilação e de morte em crianças e adolescentes é motivo de grande sofrimento tanto para quem recebe quanto para quem transmite a má notícia, demandando habilidade, controle emocional e sensibilidade dos profissionais de saúde. 
Descrever a experiência de mães de crianças e adolescentes com câncer diante da comunicação de más notícias referentes ao diagnóstico, procedimentos invasivos e cuidados paliativos. 


\subsection{Caracterização do estudo}

O presente estudo é de natureza descritiva e exploratória. Considerando seu objeto e objetivo, optamos pela metodologia de pesquisa qualitativa, visto que a experiência humana, referida pelos próprios sujeitos, é capaz de fundamentar o conhecimento sobre os indivíduos (POLIT; BECK, 2004). Tal opção também se justifica por ser valiosa tal abordagem metodológica quando se procura descobrir e compreender o significado atribuído a eventos, práticas sociais, percepções e ações dos indivíduos (BOGDAN; BIKLEN, 1994), visto que a pesquisa qualitativa não busca apenas estudar o fenômeno, mas entender seu significado individual ou coletivo para a vida das pessoas, significado esse estruturante, já que, ao seu redor, as pessoas organizam suas vidas e o próprio cuidado com a saúde (TURATO, 2005).

\subsection{Aspectos éticos}

O projeto foi aprovado pelo Comitê de Ética em Pesquisa da Escola de Enfermagem de Ribeirão Preto da Universidade de São Paulo - EERP-USP (Protocolo CAAE nº: 01186212.1.0000.5393). Como parte da documentação prevista, elaboramos o Termo de Consentimento Livre e Esclarecido (Apêndice I), por meio do qual, em linguagem simples, as mães foram informadas sobre o objetivo da pesquisa, seus procedimentos, riscos, desconfortos e benefícios, garantia do anonimato e direito de participarem ou não. Após orientação sobre a pesquisa e oportunidade de discussão, foram solicitadas suas anuências mediante assinatura do termo. Nessa ocasião, solicitamos também permissão para que a entrevista, um dos instrumentos de coleta de dados, fosse gravada.

\subsection{Local do estudo}

O estudo foi realizado na Clínica Pediátrica, especificamente no Setor de OncologiaHematologia Pediátrica, enfermarias e ambulatório do Hospital das Clínicas da Faculdade de Medicina de Ribeirão Preto da Universidade de São Paulo (HCFMRPUSP), no município de Ribeirão Preto - São Paulo. 
A instituição é um hospital-escola, nível terciário de atenção à saúde, referência para o atendimento de crianças e adolescentes com câncer. A equipe responsável pelo atendimento e assistência é multiprofissional, composta por médicos, enfermeiros, psicólogos, assistentes sociais, terapeutas ocupacionais, fisioterapeutas, nutricionistas e auxiliares e técnicos de enfermagem. As enfermarias estão localizadas no $7^{\circ}$ andar do HCFMRPUSP e contam com 40 leitos, nos quais são internados crianças e adolescentes (1 mês a 18 anos) com doenças crônicas, tais como Câncer, Fibrose Cística, Diabetes Mellitus, dentre outras. Os ambulatórios estão localizados no $2^{\circ}$ andar e organizados por especialidades como onco-hematologia, reumatologia, imunologia, gastroenterologia, endocrinologia, pneumologia, dentre outros.

\subsection{Participantes do estudo}

O convite para participar do estudo foi feito às mães de crianças e adolescentes com câncer em acompanhamento no HCFMRPUSP. A aluna/pesquisadora apresentou-se e explicou o objetivo e o propósito do estudo, bem como a garantia de sigilo das informações coletadas e a não identificação dos participantes, os quais também foram informados sobre sua livre escolha para participar.

A população foi constituída de mães de crianças e adolescentes com câncer que receberam a comunicação de uma má notícia no período da coleta de dados, podendo ser a comunicação do diagnóstico, de procedimento invasivo (implante de cateter venoso central, cirurgias) ou de mudança do cuidado curativo para o paliativo.

A seguir, no quadro 1, estão descritas algumas características dessas mães, identificadas pela letra $\mathrm{M}$, seguida de dois números que representam, respectivamente, o grupo focal e a mãe da criança e/ou do adolescente, por exemplo, M1.1, mãe, grupo focal 1 e identificação da pessoa no grupo focal. A criança e o adolescente também foram identificados, respectivamente, pelas letras $\mathrm{C}$ e A, seguidas de números. 
Quadro 1. Identificação das mães e das crianças e dos adolescentes com câncer. Ribeirão Preto, 2013.

\begin{tabular}{|c|c|c|c|c|c|}
\hline Mãe & Idade & $\begin{array}{c}\text { Criança/ } \\
\text { Adolescente }\end{array}$ & Idade & Diagnóstico & $\begin{array}{c}\text { Data da } \\
\text { coleta de } \\
\text { dados }\end{array}$ \\
\hline M1.1 & 40 anos & C1 & 1 ano & $\begin{array}{c}\text { Hepatoblastoma } \\
\text { Nódulos pulmonares }\end{array}$ & $25 / 07 / 2012$ \\
\hline M1.2 & 19 anos & $\mathrm{C} 2$ & 3 anos & $\begin{array}{c}\text { Leucemia Linfoide } \\
\text { Aguda }\end{array}$ & $25 / 07 / 2012$ \\
\hline M1.3 & 37 anos & $\mathrm{C} 3$ & 4 anos & $\begin{array}{c}\text { Germinona } \\
\text { Metástase pulmonar e } \\
\text { hepática } \\
\text { Cuidados paliativos }\end{array}$ & $25 / 07 / 2012$ \\
\hline M2.1 & 31 anos & A1 & 14 anos & $\begin{array}{c}\text { Osteossarcoma } \\
\text { Metástase pulmonar }\end{array}$ & $13 / 08 / 2012$ \\
\hline M2.2 & 25 anos & $\mathrm{C} 4$ & 4 anos & Linfoma de Burkit & $13 / 08 / 2012$ \\
\hline M2.3 & 22 anos & C5 & 1 ano & $\begin{array}{c}\text { Sistema Nervoso } \\
\text { Central }\end{array}$ & $13 / 08 / 2012$ \\
\hline M3.1 & 27 anos & C6 & 2 anos & $\begin{array}{c}\text { Hepatoblastoma } \\
\text { (recidiva) }\end{array}$ & $27 / 09 / 2012$ \\
\hline M3.2 & 31 anos & $\mathrm{C7}$ & 2 anos & Neuroblastoma & $27 / 09 / 2012$ \\
\hline M3.3 & 31 anos & C8 & 3 anos & $\begin{array}{l}\text { Leucemia Linfoide } \\
\text { Aguda (recidiva) }\end{array}$ & $27 / 09 / 2012$ \\
\hline M4.1 & 42 anos & $\mathrm{A} 2$ & 16 anos & Glioma & 03/12/2012 \\
\hline M4.2 & 38 anos & A3 & 12 anos & $\begin{array}{c}\text { Leucemia Linfoide } \\
\text { Aguda }\end{array}$ & $03 / 12 / 2012$ \\
\hline M4.3 & 20 anos & C9 & 2 meses & $\begin{array}{c}\text { Leucemia Linfoide } \\
\text { Aguda }\end{array}$ & $03 / 12 / 2012$ \\
\hline M5.1 & 25 anos & C10 & 9 anos & Meduloblastoma & 17/01/2013 \\
\hline M5.2 & 31 anos & A4 & 15 anos & Osteossarcoma & $17 / 01 / 2013$ \\
\hline M5.3 & 27 anos & C11 & 7 anos & Neuroblastoma & $17 / 01 / 2013$ \\
\hline M6.1 & 23 anos & C12 & 5 anos & $\begin{array}{c}\text { Linfoma Linfoblástico } \\
\text { de SNC (recidiva) }\end{array}$ & $22 / 01 / 2013$ \\
\hline
\end{tabular}




\begin{tabular}{|c|c|c|c|c|c|}
\hline Mãe & Idade & $\begin{array}{c}\text { Criança/ } \\
\text { Adolescente }\end{array}$ & Idade & Diagnóstico & $\begin{array}{c}\text { Data da } \\
\text { coleta de } \\
\text { dados }\end{array}$ \\
\hline M6.2 & 40 anos & C13 & 4 anos & $\begin{array}{c}\text { Leucemia Linfoide } \\
\text { Aguda }\end{array}$ & $22 / 01 / 2013$ \\
\hline M6.3 & 26 anos & C14 & 3 anos & $\begin{array}{c}\text { Leucemia Linfoide } \\
\text { Aguda }\end{array}$ & $22 / 01 / 2013$ \\
\hline M7.1 & 41 anos & A5 & 15 anos & Sarcoma Sinovial & 29/01/2013 \\
\hline M7.2 & 32 anos & C15 & 2 anos & $\begin{array}{c}\text { Sarcoma de Células } \\
\text { Claras Renal }\end{array}$ & 29/01/2013 \\
\hline M7.3 & 33 anos & A6 & 16 anos & $\begin{array}{c}\text { Leucemia Linfoide } \\
\text { Aguda }\end{array}$ & 29/01/2013 \\
\hline M8.1 & 31 anos & C16 & 3 meses & $\begin{array}{c}\text { Leucemia Mieloide } \\
\text { Aguda }\end{array}$ & $28 / 03 / 2013$ \\
\hline M8.2 & 26 anos & C17 & 10 meses & $\begin{array}{c}\text { Neuroblastoma } \\
\text { Metastático }\end{array}$ & $28 / 03 / 2013$ \\
\hline M8.3 & 35 anos & C18 & 4 anos & Meduloblastoma & $28 / 03 / 2013$ \\
\hline
\end{tabular}

\subsection{Procedimentos para coleta e registros dos dados}

Como instrumento para a coleta de dados, utilizamos grupos focais com o objetivo de descrever a experiência das mães diante da comunicação de más notícias em relação à doença de seu filho, podendo ser sobre o diagnóstico, necessidade de procedimentos invasivos ou mudança dos cuidados curativos para paliativos.

Entre as finalidades do grupo focal, destaca-se a possibilidade de reunir os atores em um espaço de investigação com o objetivo de produzir dados. Segundo Beeck, Gonzales e Leopardi (2002), a coleta de dados por meio do grupo focal consiste em um método de coleta diretamente das falas de um grupo, que relata suas experiências e percepções em torno de um tema de interesse coletivo. Os participantes devem ter alguma vivência com o tema a ser discutido de tal modo que sua participação possa trazer elementos ancorados em suas 
experiências cotidianas (GATTI, 2005). Grupos focais podem ser preexistentes ou formados para fins de uma investigação.

Segundo Minayo (2004), o grupo focal consiste em uma técnica de inegável importância para trabalhar questões de saúde sob a perspectiva do social, por se dirigir ao estudo de representações e relações dos diferenciados grupos de profissionais, processos de trabalho e também da população.

Tipicamente, o grupo focal é composto por três a dez participantes, com características comuns, as quais estão associadas ao tópico a ser pesquisado. Usualmente, a duração de um grupo é de uma hora a uma hora e meia, dependendo do número de participantes. Na fase de organização, é importante determinar um espaço para a realização do grupo, o qual que deve propiciar um ambiente tranquilo de forma a preservar a privacidade dos participantes, sem ruídos, uma vez que há uso de gravador nas reuniões (KRUEGER, 1988; DEBUS, 1994).

Nas reuniões, o moderador do grupo é o próprio pesquisador que contará com a ajuda de um assistente (observador), cuja tarefa é registrar todos os acontecimentos no campo grupal, incluindo aspectos não verbais presentes na comunicação dos participantes, apreendendo suas atitudes, preocupações e linguagem (DEBUS, 1994; BECK, GONZALES, LEOPARDI, 2002).

Dessa forma, a etapa operacional, ou seja, a coleta de dados, foi realizada na instituição anteriormente mencionada, no período de julho de 2012 a março de 2013, após a aprovação do protocolo pelo Comitê de Ética em Pesquisa. Diariamente, no período matutino, foi realizada consulta aos registros dos diferentes setores com a finalidade de identificar os potenciais participantes, os quais foram convidados a participar do estudo se confirmados os critérios de inclusão.

Foram realizados oito grupos focais, cada um com três mães, totalizando vinte e quatro participantes, com tempo de duração médio de 60 minutos. Os grupos focais foram conduzidos por um moderador (pesquisador), responsável pela condução do grupo, e uma observadora, que deveria observar a conduta do grupo e realizar anotações de pontos relevantes.

Para a realização dos grupos focais, foram consideradas a realidade e a rotina da Unidade de Onco-Hematologia e das mães participantes. Contatos prévios ocorreram intencionando conhecê-las e explicar-lhes o objetivo dos grupos focais e da pesquisa e também para determinar o melhor horário para realização da coleta de dados. O local de realização dos grupos foi determinado em conjunto com a equipe de enfermagem da unidade de forma a não prejudicar a rotina de trabalho da equipe de enfermagem e médica, sempre 
atentando para questões de privacidade e silêncio; todos os encontros dos grupos foram gravados mediante a autorização das mães. Também procuramos evitar distanciá-las de seus filhos caso os mesmos delas necessitassem para algum procedimento; quando necessário, o grupo era interrompido por determinado tempo.

Inicialmente era realizada a apresentação da pesquisadora e da observadora, seguida da apresentação de cada mãe; todos os integrantes permaneciam sentados em círculo, favorecendo a visualização e a comunicação entre eles. Após as apresentações, eram explicitados objetivos da pesquisa e do grupo, bem como sua forma de condução.

Antes de iniciar a coleta de dados, foi realizada a leitura prévia do Termo de Consentimento Livre e Esclarecido (TCLE) para que os participantes fossem esclarecidos em relação aos aspectos éticos, aos objetivos, ao tempo estimado de duração do grupo e como ele seria conduzido. Com anuência das mães, as participações eram firmadas mediante a assinatura do TCLE, sendo que uma via era entregue a elas; nesse momento, era solicitada autorização dos participantes para gravação dos grupos.

O foco da discussão consistiu em conhecer e explorar a experiência das mães de crianças e adolescentes com câncer diante da comunicação de más notícias. A condução dos grupos foi realizada mediante instrumento desenvolvido pela pesquisadora contendo questões que estimulavam as mães a interagirem, conversarem e compartilharem as experiências vividas sobre o tema proposto. A estrutura do instrumento (Apêndice II) constou de duas partes: a primeira com informações dos participantes da pesquisa como idade, sexo, escolaridade, ocupação, procedência, religião, diagnóstico do filho e, a segunda, contendo as questões norteadoras que remetem ao objetivo do estudo tais como: o que você considera uma notícia difícil; qual foi a notícia difícil; qual a compreensão frente à comunicação da notícia difícil; quais outras experiências teve com a comunicação de uma notícia difícil, dentre outras questões.

Ao final dos grupos, uma síntese da discussão era elaborada pelo moderador, sendo oportunizado aos participantes acrescentar opiniões, dúvidas, questionamentos e novas ideias, além da avaliação da atividade realizada.

De forma complementar, recorremos aos prontuários das crianças e dos adolescentes com a finalidade de buscar informações relacionadas aos diagnósticos, mudanças de tratamentos, condutas e intercorrências. 


\subsection{O processo de análise dos dados}

A análise do material empírico originário dos grupos focais e dos dados do prontuário foi realizada de forma minuciosa segundo o processo de análise de conteúdo do tipo temática indutiva, realizada em seis etapas, segundo orientações de Braun e Clarke (2006). Para esses autores, esse método visa identificar, analisar e relatar padrões com base em dados coletados. Tais padrões são denominados temas e representam partes significativas do conjunto de dados.

No modelo indutivo, os temas identificados são extraídos dos próprios dados. Assim, a análise indutiva é um processo de codificação dos dados que não dizem respeito a nenhuma estrutura preexistente (teoria) ou a preconcepções do pesquisador (extraídas da revisão da literatura), ou seja, é direcionada e embasada pelos próprios dados (BRAUN, CLARKE, 2006).

A primeira etapa teve como objetivo realizar uma imersão nos dados para reconhecer a amplitude e profundidade do conteúdo, transcrevendo as entrevistas, lendo e relendo atentivamente todos os dados obtidos e identificando ideias iniciais importantes. Na segunda etapa, foram realizadas a identificação e a criação sistemática de códigos para as unidades significativas, processo que pode ser feito manualmente ou por meio de um software. $\mathrm{Na}$ terceira etapa, realizamos a revisão das unidades significativas, os agrupamentos e a construção de temas. Na sequência, na quarta etapa, revisamos os temas e sua validade em relação aos códigos e aos dados e, na quinta, procedemos à nomeação dos núcleos temáticos. Braun e Clarke (2006) recomendam que os títulos sejam concisos de forma a possibilitar imediatamente ao leitor a noção do que será abordado. Para finalizar, a sexta etapa é a de elaboração do relatório final com a análise e realização da interpretação dos núcleos temáticos com os achados da literatura, o contexto dos participantes e as reflexões do pesquisador.

Para isso, realizamos a transcrição integral das gravações, complementadas com as informações obtidas nos prontuários e com as observações registradas em diário de campo. Buscou-se preservar o máximo possível as expressões de linguagem dos participantes e, para melhor compreensão dos relatos, foram feitas correções que não alteraram o significado da frase. Esse procedimento ocorreu logo após a realização de cada grupo focal.

Na condição de ferramenta de apoio para análise dos dados, o programa MAQXDA foi utilizado. Trata-se de um programa de CAQDAS (Computer Aided Qualitative Data Analysis Software) que auxilia a análise qualitativa dos dados, como a contagem de palavras, palavras-chaves, recuperação de um contexto, indexação de palavras e construção de análise de discurso. Neste estudo, o MAXQDA auxiliou na pré-análise do material, na exploração e 
codificação dos dados empíricos e no tratamento dos resultados. Os depoimentos selecionados após a leitura dos dados empíricos foram importados para o software, dentro de cada código principal, onde o programa MAQXDA realizou automaticamente a contagem de itens dentro de cada código (MAQXDA, 2013).

Desse modo, foi elaborado um quadro para exemplificar como ocorreu a criação de cada código.

Quadro 2 - Organização do material empírico

\begin{tabular}{|c|c|}
\hline Tema & Trechos dos grupos focais \\
\hline A comunicação da má notícia & $\begin{array}{l}\text { “O complicado é quando a pessoa fala para você: é } \\
\text { leucemia, é raro e é o primeiro caso que eu já vi. Eu sei } \\
\text { que essa pessoa tem anos e anos de profissão e ela joga } \\
\text { você lá no chão, se ela que tem a experiência e que nunca } \\
\text { viu num bebê, como que vai ser?(M8.1)”. } \\
\text { "Primeiro eu já sai do Cuiabá [unidade distrital de } \\
\text { saúde] com um papel escrito tumor. Não foi nem aqui, foi } \\
\text { de lá que eu sai com o papel, com o diagnóstico escrito } \\
\text { (M8.2)”. } \\
\text { “... o médico chegou e falou: mãe, o que vou dizer é que } \\
\text { o seu filho tem um tumor e que vai precisar operar a } \\
\text { cabeça dele e no laudo é maligno. Eu olhei e falei: como } \\
\text { que é? Ele falou: é um câncer maligno (M8.3)”. }\end{array}$ \\
\hline $\begin{array}{l}\text { A revelação da notícia para a criança e } \\
\text { adolescente }\end{array}$ & $\begin{array}{l}\text { "Nunca quisemos esconder dele a gravidade do } \\
\text { problema, mesmo assim ele teve uma recaída (M7.3)”. } \\
\text { “... eu, como mãe, não queria, mas se eu tivesse } \\
\text { escondido dele hoje talvez ele não tivesse com essa garra, } \\
\text { desse jeito que ele esta hoje, ele conseguiu lidar com o } \\
\text { problema e achar uma solução do jeito dele, cada um } \\
\text { escolhe um jeito. As pessoas são diferentes e ele achou o } \\
\text { jeito dele de superar isso. Só que eu acho que família é } \\
\text { muito importante nessa hora, porque se ele estivesse } \\
\text { sozinho talvez ele não conseguisse (M7.1)”. }\end{array}$ \\
\hline Comunicação dos cuidados paliativos & $\begin{array}{l}\text { "O mais difícil é quando o doutor falou hoje para mim: } \\
\text { mãe, ela está com cinco antibióticos mais um antifúngico } \\
\text { e ela não responde a nenhum, não sabemos mais o que } \\
\text { fazer. É grave, grave, grave (M8.1)". } \\
\text { "E hoje quando o doutor falou para mim que ela não está } \\
\text { respondendo a nenhuma medicação e o que podíamos } \\
\text { ter feito, fizemos, não sabemos o que fazer porque ela não } \\
\text { reage, ela não responde à medicação (M8.1)”. } \\
\text { “... o tratamento dele não está obtendo resposta (M4.3)”. }\end{array}$ \\
\hline
\end{tabular}


O material empírico foi organizado ao redor de três temas: A comunicação da má notícia, descrito com base na revelação do diagnóstico de câncer, no modo de comunicar, na compreensão diante da notícia; A revelação da notícia para a criança e adolescente, que trata da comunicação com a criança e o adolescente, os envolvidos no processo de revelação do diagnóstico, abrangendo o autocuidado e a tomada de decisão; Comunicação dos cuidados paliativos, referente à comunicação da mudança de cuidado curativo para os cuidados paliativos.

\subsection{Comunicação da má notícia}

Observamos que um dos aspectos em comum a todos os grupos focais foi a revelação do diagnóstico de câncer como a primeira comunicação de má notícia. Todas as participantes relataram que o momento do diagnóstico foi de muita dificuldade para a aceitação da doença em decorrência do medo da morte do filho. Relataram, também, sentimentos de dor, sofrimento, angústia e desespero:

(...) quando eu descobri que ele estava com o diagnóstico de câncer eu fiquei sem chão, (...) eu vi essa doença como uma coisa que mata, que não tem cura, mesmo fazendo o tratamento, e depois de algum tempo a gente sabe que volta, (...) para mim foi a pior notícia que eu tive (...) M1.1.

Praticamente foi receber o diagnóstico, foi um susto. O câncer eu não esperava M2.1.

A notícia quando me deram, só fiz chorar. Chorar. Chorar M3.3.

Eu não sei o que aconteceu que eu entrei em choque. Eu entrei em choque M6.2.

a doutora entrou na sala e falou: saiu o resultado do exame, eu achei que ela estava aflita também em falar, ela falou: mãe, saiu o resultado do exame, deu positivo para leucemia M6.2.

Naquela hora eu me segurei muito, mas a minha vontade era de gritar. Esgoelar um pouco sabe, desabafar mesmo. Mas eu me segurei na frente deles também, eu não chorei, nem nada, mas com aquela vontade de... Então eu liguei para a minha cunhada e eu desabafei. Desabafei. Mas eu chorei, chorei, chorei M4.2. 
A comunicação de notícias ruins, notadamente no que se refere ao diagnóstico de enfermidades progressivas como o câncer, consideradas algumas vezes como incuráveis, não é uma tarefa fácil de ser realizada (GOMES et al., 2009). No caso do câncer, elas são constantemente transmitidas, considerando que a doença desencadeia uma série de mudanças na vida do paciente e de sua família, sendo muitas vezes a precursora de outras informações negativas, impondo restrições na qualidade e tempo de vida (GEOVANINI, 2011).

Ao mesmo tempo, pacientes e familiares evitam pronunciar a palavra câncer, referemse à enfermidade como aquela doença e segundo Araújo e Silva (2007) ao evitarem a referência direta utilizam um discurso rico em figuras de linguagem, especialmente metáforas. Isso também foi verificado na presente investigação, uma vez, que as mães relataram a dificuldade em pronunciar a palavra câncer elegendo outra em substituição:

A médica vira e fala que ela tem um câncer, uma que essa palavra eu nem falo, é muito forte e eu nem gosto de falar M3.2.

Eu prefiro falar tumor M3.1.

A família, muitas vezes, não espera pelo diagnóstico de câncer e quando este é firmado sente-se abalada e desestruturada e, em algumas situações pode e acaba criando um luto antecipado. Nesse período ocorrem reações emocionais características como, por exemplo, culpa, solidão, desapontamento, raiva e desespero, chegando a negar a doença (PAI et al., 2010).

Assim, habitualmente, informar más notícias provoca perturbação tanto para o paciente e seus familiares quanto para a pessoa que as comunica e segundo Twycross (2003), é necessário estar preparado para enfrentar uma reação emocional intensa que envolve lágrimas, choro e revolta.

Especial atenção deve ser dispensada à comunicação com os familiares de crianças e adolescentes. Em geral, eles mostram-se desejosos de informação, depositando no médico a demanda por esclarecimentos sobre a extensão e a evolução da doença. À criança e ao adolescente também deve ser dispensado o mesmo padrão de comunicação estabelecido com os pais. É importante que o médico tenha disponibilidade para escutar, conhecendo assim a história familiar, os anseios, as dúvidas e os medos, além de fornecer informações, de forma clara e objetiva a respeito do diagnóstico e prognóstico da doença (GEOVANINI, 2011).

O diagnóstico de uma doença grave que envolve risco de vida, incapacidades e outras perdas provoca sentimentos intensos e dolorosos no paciente e na família, bem como na 
equipe de saúde. Apesar de ser uma tarefa inevitável para o médico, comunicar más notícias permanece sendo uma parte difícil e especial do trabalho do profissional de saúde (RIBA; JUVER, 2008).

A ausência de informação ou a comunicação deficiente geram no paciente e familiares um sentimento de insegurança em relação à doença, ao prognóstico e à equipe de saúde. $\mathrm{O}$ modo como se comunica o diagnóstico afeta, de forma importante, a maneira pela qual pacientes e famílias irão reagir à revelação (RIBA; JUVER, 2008).

No caso de crianças e adolescentes com câncer, os pais vivenciam diferentes momentos e associam o adoecimento e o tratamento a aspectos negativos como o sofrimento, dor, medo de perder o ente querido, demonstrando, ao final, esperança, quase que incondicional, da cura (LACAZ, 2003). Esse foi um aspecto presente nos grupos focais, ocasião em que as mães, sem exceção, relataram a esperança de cura da doença de seu filho. Em seus depoimentos, mesmo quando verbalizavam compreender que o diagnóstico é de uma doença grave, com tratamento prolongado, mencionando o medo da morte, também ressaltavam a esperança da cura, de verem seu filho curado do câncer, sempre acreditando no sucesso do tratamento a ser realizado:

(...) tem esperança da cura sim, muita, acho que noventa por cento de chance de curar (...) M7.1.

Eu até falei: doutora então vamos, vamos tentar a radioterapia, e ela falou assim: olha nós vamos tentar, mas eu não estou dando muita chance de vida para ela, e eu falei: mas mesmo assim vamos lutar, enquanto há vida há esperança, há esperança de cura M1.3.

A idade que ele tem agora, não é fácil de tratar, é complicado, o caso dele já esta fora do protocolo, (...) o lugar que ele está só complica, mas nós vamos continuar lutando, ele é bem corajoso e ele quer viver e nós vamos continuar tentando enquanto der M5.3.

O que ajudou muito para mim, na hora que deu o diagnóstico, foi que tinha umas mães lá em baixo [no ambulatório ]que eram da reunião dos curados, que tem aqui uma turma de crianças que já foi curada (...) M6.2.

As mães se apegam bastante em saber que têm muitas crianças curadas. Eu me apego bastante nisso M6.1.

A expectativa de cura é fortemente influenciada pelo vínculo e segurança transmitida pelos profissionais de saúde à família e à criança e o adolescente (CAMPOS et al., 2007). Na interação estabelecida, a família percebe o quanto a transmissão de mensagens de otimismo e 
esperança beneficia a criança e o adolescente, pois eles, ao dialogar com a sua família, expressam a esperança de cura e o desejo de voltar para casa. A família percebe que a criança e o adolescentes acreditam e sonham com uma vida nova, prosseguindo em sua trajetória pela busca da sobrevivência, o que deixa o núcleo familiar confiante e tranquilo. Sanchez (2010) assinala que, em um processo mental, família e paciente consideram as experiências vividas, o que está ocorrendo no presente, e tentam prever as possibilidades do futuro, interagindo e definindo a situação no presente.

Durante a comunicação de más notícias sobre a situação clínica de seu filho, as mães relataram ser fundamental haver, por parte do médico e membros da equipe de saúde que já possuem vínculo e acompanham o tratamento, participação e disponibilidade. Mencionaram também a importância da presença do médico da unidade de onco-hematologia nos momentos de situações de agravamento do quadro e de intercorrências como febre, neutropenia febril e reações adversas na administração de quimioterápicos:

(...) lógico que os outros também são médicos, mas eles não sabem aqui o que cada criança tem, o que está passando, (...), então como ontem que ela teve febre, o médico estava atendendo uma outra criança, quer dizer, ele já estava atendendo e ele não vai sair de lá correndo para vim aqui, porque aqui é do isolamento, então você percebe que se fosse uma coisa bem séria, talvez não teria dado tempo de reverter (...) M3.1.

(...) os problemas daqui que eu já falei, é que esses médicos ainda mais quando troca, eles não sabem absolutamente nada do que eles estão te falando, (...) eu acho que no mínimo eu teria que ser atendida por um médico que já está aqui faz tempo, que já sabe dos meus problemas. Está certo que é estudante, só que eu acho, eu não tenho mais condições psicológicas e emocionais para ficar conversando com eles, não tenho, de verdade M5.3.

Eu acho assim que o que precisaria mudar é em relação a ficar um médico da oncologia aqui de plantão. (...) eu acho que se ficasse um deles aqui seria muito mais fácil e acaba que nós temos mais confiança também M3.1.

No momento do diagnóstico, o nível de ansiedade de pais e filhos é muito alto e a necessidade de informação e capacidade de compreensão variam bastante. Eles querem saber, o quanto for possível, sobre a doença, o tratamento, os procedimentos, o prognóstico, detalhes do cuidado domiciliar e impactos emocionais. A comunicação do diagnóstico e do plano de tratamento deve ser realizada de modo a responder tais necessidades de informação e possibilitar o estabelecimento de confiança entre a equipe profissional, o paciente e sua família. Sendo assim, essa comunicação não pode e não deve ser delegada a membros da 
equipe não fixos e estáveis, que podem ou não comunicar adequadamente, mas que certamente não estarão presentes no decorrer do tratamento (SIOP, 2004).

Silva e Zago (2005) argumentam que ao relevarem o diagnóstico para a família, os profissionais de saúde devem ter em mente o impacto que ela pode sofrer; no entanto, não podem negligenciar informações sobre a doença. Além disso, quando os pais acreditam que estão sendo respeitados e que recebem informações necessárias sobre diagnóstico, prognóstico e tratamento do seu filho, eles têm maior probabilidade de se adaptarem continuamente às novas situações, pois se sentem mais seguros e preparados (BRODY; SIMMONS, 2007).

Apesar dos avanços na área de oncologia, pouca ênfase tem sido direcionada aos programas de treinamento relacionados à habilidade de comunicação, requisito necessário para atendimento a pacientes oncológicos e seus familiares. Assim, os profissionais dependem então de sua experiência clínica e julgamento pessoal no que se refere à decisão de informar ao paciente e familiares sobre a doença, bem como sobre a melhor maneira e momento de fazê-lo (CAVALCANTI, 2005). Nesse sentido, as mães mencionaram que:

(...) a médica entrou e disse: mãe seu filho esta com câncer, bem no meio das seis camas [na enfermaria], (...) o câncer dele é do tamanho de uma bola, amanhã vamos fazer uma biópsia às dez horas da manhã para saber o que ele tem, se tirarmos essa bola fazemos futebol aqui hoje, eu acho que ela queria ir embora, eu não sei o que ela queria fazer (...) M5.3.

O diagnóstico (...) o médico foi muito atencioso e educado para me dar (...), mas o prognóstico de cura não foi muito bom não, porque a médica que me passou já me deixou lá embaixo, ela disse que tinha que esperar um milagre, foi do jeito que ela me falou. Vamos esperar um milagre porque eu nunca vi,é a primeira vez que vejo em uma bebê, muito difícil, então vamos esperar M8.1.

\section{(...) o momento que aconteceu de dar a notícia eu estava sozinha (...) M1.2.}

Vale dizer que comunicar uma notícia não é simplesmente informar e retirar-se. Tratase de um longo processo, desenvolvido em várias etapas, pois, algumas informações terão que ser repetidas em outros momentos, considerando que as pessoas sob grave impacto emocional geralmente não assimilam bem o que é transmitido e comunicado, mesmo que a linguagem utilizada seja compreensível (KOVÁCS, 2006).

As mães participantes do estudo, dadas as características do serviço, receberam a comunicação de uma má notícia em ambiente não próprio e adequado para tal momento. Muitas vezes, a comunicação entre médico, paciente e familiares ocorre em salas que 
oferecem pouco conforto e limitada privacidade. Observa-se a ocorrência da comunicação nos corredores, próxima a outros profissionais e até de pessoas desconhecidas da família e do paciente, o que gera constrangimento, além de tornar a comunicação impessoal, sem vínculo e desrespeitar a privacidade do outro. A comunicação também ocorreu nas enfermarias, local sem a devida privacidade:

Eles [os médicos] deviam ter me chamado num outro lugar, conversado comigo em outro local, (...) do jeito que foi todo mundo ficou sabendo. Foi horrível continuarmos ali [na enfermaria] depois, porque ele já virou o patinho feio do quarto e todo mundo olha (...) o moleque esta com câncer (...) M5.3.

O diagnóstico foi no quarto mesmo M4.2.

(...) deviam ter me chamado num outro lugar, conversado comigo em outro local, em um lugar fechado M5.3.

Eu estava sozinha no momento da notícia, mas depois que caiu a ficha eu liguei para o meu marido, a princípio eu passei para ele a notícia que a doutora tinha passado M6.1.

A noite a doutora entrou no quarto e disse que queria conversar comigo, $e$ disse, mãe realmente é leucemia linfóide aguda e eu estava sozinha, entrei em desespero, então liguei para o meu marido M1.2.

Ás vezes o próprio ambiente pode provocar o fracasso na comunicação de más notícias e na abordagem de assuntos sensíveis. Assim, é pertinente a privacidade do ambiente para que se possa conseguir uma discussão focada e sem distrações e interferências. É importante, também, envolver pessoas próximas do paciente e familiar para a comunicação de uma má notícia (BAILE et al., 2000).

Na linguagem utilizada na comunicação com a família, os profissionais de saúde costumam usar símbolos, cujos significados não são compartilhados pelos pais e filhos, o que dificulta a compreensão (SANCHEZ, 2010). O núcleo familiar só inicia a construção de uma relação de confiança com o profissional de saúde se o considerar fonte de apoio emocional e informacional no momento em que o mesmo estabelece uma comunicação sincera, permeada pelo respeito e atenção à família (SILVA; ZAGO, 2005).

É fundamental lembrar que quando a comunicação envolve algum tema delicado ou difícil, necessita também ser feita de maneira sensível, sem pressa, em ambiente adequado, com poucos ruídos e interferências, de modo que possa ser compreendida. Uma boa 
comunicação afeta positivamente o estado de ânimo do paciente, sua adequação psicológica à situação e sua qualidade de vida (SILVA, 2008).

O estigma que a doença carrega também esteve presente no depoimento das mães, por exemplo quando uma verbaliza que seu filho virara o patinho feio do quarto e todo mundo olha (...) ou ainda quando dizem:

Porque tudo vem também de um grande mito da palavra câncer, antigamente tratamento quase não tinha, então falava câncer em poucos meses a pessoa já estava falecendo (...) M8.1.

Porque para nós que não sabemos destas coisas da doença [do câncer], sabemos só pela televisão, então quando falam de câncer a primeira coisa que vem na nossa cabeça é morte M1.2.

(...) quando eu fiquei sabendo do diagnóstico de câncer eu fiquei sem chão, porque eu sempre vi essa doença como uma coisa que mata, que não tem cura, mesmo fazendo o tratamento depois de algum tempo nós sabemos que ela volta e vai devastando tudo M1.1.

Para Goffman (1988), o estigma ocorre em situações nas quais o indivíduo não possui a aceitação social plena. É atributo profundamente depreciativo, que distingue o indivíduo dos demais que se encontra em determinada categoria social. O estigma se apoia nas diferenças, ou seja, não aquilo considerado normal, mas desviante ou patológico. Além do indivíduo que possui a característica estigmatizante, as pessoas próximas a ele, tal como familiares e amigos, passam a compartilhar do estigma, vivendo então o estigma de cortesia.

Na situação de uma doença crônica é frequente o uso do termo personalidade do doente crônico, caracterizada pela presença de depressão, ansiedade, baixa autoestima e forte dependência dos pais. Alguns autores (KOVACS et al., 1997) contestam tal tipologia pelo seu caráter estigmatizante argumentando que as crianças e adolescentes com doenças crônicas têm sim modos peculiares de viver, o que é diferente de os catalogar em razão de uma característica genérica.

Neste sentido, apesar dos avanços científicos e tecnológicos alcançados na área médica, como já mencionado, o câncer ainda é uma doença estigmatizante para muitos profissionais de saúde, notadamente médicos; e tal postura interfere no modo como pacientes e seus familiares lidam com o diagnóstico, o qual permanece sendo associado à possibilidade de sofrimento físico, emocional e morte (CAVALCANTI, 2005; GOMES et al., 2009). Ainda, o preconceito e o estigma estão presentes em outros contextos sociais nos quais existam 
dificuldades tanto das crianças e dos adolescentes quanto de suas famílias de enfrentarem as doenças crônicas (GON et al., 2005).

Ter uma doença crônica como o câncer e ser diferente da população em geral, por exemplo, pela alopécia, uso de máscara, retornos frequentes ao hospital, pode implicar no estigma e lidar com o mesmo envolve uma variedade de estratégias, incluindo a decisão de divulgar sua condição (JOACHIM; ACORN, 2000). Algumas mães mencionaram as dificuldades encontradas com as marcas da doença:

(...) fazer o exame, todo dia ter que tirar sangue, todo dia ter que furar, todo dia quimioterapia, ver o cabelinho dela cair, dói demais, ás vezes eu evito pentear o cabelo dela porque esta caindo muito M1.2.

Uma que tirou o cabelão dele, porque ele adorava o cabelão dele comprido e ele falou assim: vou ter que ficar careca. Já começou por ai. Ele não quis ir à escola, ele ficou assim completamente só no computador, os amigos ligavam para ele, ele falava que não estava M7.1.

Falar para ela que tinha um tumor, um câncer, foi uma criança que ficou com medo de perder a perna, de sair na rua e as pessoas olharem com diferença, ir à escola, ela não quer ir à escola, não se sente bem de sair na rua, fica mais deitada em casa numa cama, então, é uma parte muito difícil M5.2.

Assim, estas mães mencionaram a associação das características do câncer com o sentimento de medo, de dor e de perda, bem como as repercussões da doença na dimensão emocional e física de seus filhos. Também foi destacada a mudança na rotina para melhor cuidado do filho com câncer:

Não quis ir embora para a minha cidade, eu fiquei aqui, chega lá todo mundo fica sabendo, então você chega, você anda na rua, todo mundo fica olhando M3.2.

Eu dei o meu quarto para ele porque tem banheiro junto, para ninguém usar o banheiro, só ele que usava aquele banheiro, só ele que usa até hoje; para entrar lá no quarto onde ele estava, tinha que tirar o chinelo lá na portinha para entrar M7.1.

(...) e eu pensava nessa parte também, como eu vou ficar aqui sem trabalhar, eu tenho saúde, tenho força, vontade de trabalhar, mas eu não vou poder trabalhar, porque eu vou ficar, eu tenho que cuidar dela M1.3.

Na trajetória para o tratamento do filho, os pais e outros membros da família enfrentam longos períodos de hospitalização, reinternações frequentes, terapêutica agressiva, dificuldade de separação dos familiares, mudança das atividades diárias, dor, sofrimento, 
dificuldade financeira e o constante medo da morte (NELSON, 2006). Em meio à realidade desconhecida, os pais buscam informações para o redimensionamento de suas atividades, agora em função da criança adoentada (PEDRO, 2008). Mesmo enfrentando as adversidades impostas pelo câncer, a família, tem em geral, capacidade de se reconstruir e se fortalecer, obtendo resultados satisfatórios (FIAMENGHI; GERALDO; MESSA, 2007; NORONHA et al., 2009).

Diante do redimensionamento de papéis e da vivência das variadas situações, a família vai se adaptando, aprendendo a manter o equilíbrio físico e emocional e se tornando parceira da equipe de saúde para atender às necessidades de cuidado à criança, apesar de ser um momento difícil (MACKAY; GREGORY, 2010; NORRIS et al., 2010).

Quando a família recebe um diagnóstico, como o do câncer infanto-juvenil, ela se vê imersa a sentimentos de perda e diante de situações complicadas de lidar. (BORGES, 2013), isto porque desde seus primórdios e ainda nos dias atuais, o câncer é uma doença revestida de grande significado simbólico, associado a ideias e sentimentos de punição e culpa. Muitas teorias psicológicas contribuíram para esse pensamento, difundindo a crença de responsabilidade do sujeito na produção da doença, bem como na sua remissão, seja pelos traços de caráter, como a resignação ou pela repressão das emoções (SONTAG, 1984).

A ameaça de morte iminente gera no doente e na família um estado de crise, como eventos de ruptura, uma vez que as expectativas de desempenho no futuro desintegram-se e projetos perdem o sentido. Em momentos de crise, é necessário buscar apoio para encontrar fortalecimento e conforto, os quais, por sua vez, podem possibilitar novas propostas que produzam prazeres em suas vidas (SANCHO, 2006).

Apesar da sobrecarga física e emocional as quais os profissionais de saúde estão submetidos, outro aspecto importante a se considerar é que para acompanhar e dar suporte aos pacientes oncológicos e suas famílias, é necessário disponibilidade que não vem sem um preparo, o qual, geralmente, não é oferecido pela formação profissional e nem se encontra nos programas de educação permanente nos espaços institucionais. A falta de preparo dos profissionais de saúde pode gerar silenciamento, falsas promessas de cura ou comunicações abruptas de prognósticos adversos causando sofrimento para os pacientes e profissionais, com prejuízos à relação terapêutica (BRASIL, 2010).

O sofrimento causado por uma má notícia é de algum modo minimizado se o profissional de saúde expressar consideração pelos sentimentos do paciente e seus familiares e as respostas às suas dúvidas e receios glhe derem confiança e segurança de que será cuidado. Comunicar uma má notícia requer, portanto, perícia, conhecimento, sensibilidade, aptidões 
específicas e tato, os quais podem ser aprendidos e desenvolvidos ao longo da vida (RIBA; JUVER, 2008).

Desta forma, para que a equipe de saúde, em particular os médicos, alcançar uma comunicação efetiva deve avaliar o conhecimento do paciente e da família, avaliar suas dúvidas e questões, ser empática, falar pausadamente e utilizar linguagem clara e objetiva, dizer a verdade, estar atenta aos comportamentos não-verbais, conhecer os valores espirituais, culturais e a rede de apoio social do paciente e da família e, estar preparada para manejar as reações dos paciente e familiares ao receberem a comunicação de más notícias (MALDONADO; CANELLA, 2009; SILVA, 2003; TRAVALINE; RUCHINSKAS; DÁLONZO, 2005;). Ainda, Bascuñán (2005) recomenda uma série de cuidados como a preparação pessoal e do ambiente físico, exploração da informação que o paciente já possui, investigar o desejo do paciente em receber informação, compartilhar as informações com o paciente e família, acolher os seus sentimentos, esclarecer dúvidas e oferecer continuidade no atendimento, cuidado e tratamento.

No âmbito da formação, Ruiz-Moral (2007) ressalta alguns pontos para melhorar a relação profissional de saúde e paciente, a necessidade de se ampliar o ensino para além das teorias biomédicas na formação profissionais de saúde, incorporando conhecimentos das áreas humanas; valorização do paciente e dos resultados esperados por ele; importância da formação pessoal e ética, como também, a incorporação de habilidades técnicas e uma atitude reflexiva, considerando cada encontro com o cliente único e singular. Tais habilidades não são privativas do médico, portanto devem ser implementadas nos cursos da área de saúde como um todo.

\subsection{A revelação da notícia para a criança e adolescente}

Durante a abordagem com as mães sobre a revelação de uma má notícia ao filho como o diagnóstico de câncer, o prognóstico e o tipo de tratamento, identificamos uma diversidade de respostas. Algumas mães relataram que a criança e o adolescente não precisam ter conhecimento da doença e do tratamento e também não devem ter participação ativa nesse processo, pois, para elas, os filhos poderiam assim manter uma melhor condição emocional e até mesmo clínica. Relataram que se não souberem da real situação, podem enfrentar 
positivamente o tratamento e a evolução da doença; algumas ainda acreditam que desconhecimento da doença pelo filho aumenta a chance de cura do câncer:

A criança não, ela não sabe o que está acontecendo. (...) então eles não entenderem as vezes ajuda a criança a enfrentar e curar a doença M2.3.

Eu já queria poupa-lo disso, porque eu acho que quando a pessoa não tem consciência da gravidade ela fica mais light, o psicológico, então eu acho que ela se cura mais fácil (...) M7.1.

E eu disse, eu tenho que contar para ele que ele pode brincar, que ele vai viver, que ele tem que comer, não contar isso [o câncer] aí para ele. (...) ele pensa que esta doente e que ele precisa tomar remédio, ele não precisa saber da doença M8.3.

Ele sabe que fez uma cirurgia na cabeça. Porque ele acha que caiu e teve que tomar ponto, mas ele fala, se você perguntar para ele, ele fala que não tem nada na cabeça dele M8.3.

Nota-se que a família tem preocupações e dúvidas sobre a comunicação com a criança e adolescente a respeito de seu adoecimento. Pais cujos filhos têm câncer relutam em falar com eles sobre o adoecimento, pois acreditam que assim poderão poupá-los do sofrimento e estigma da doença (RABUSKE, 2004). Para esses pais, trata-se de uma estratégia de proteção contra os efeitos psicossociais e as incertezas que o adoecimento pode provocar na vida da criança e da família (CLAFLIN; BARBARIN, 1991).

$\mathrm{Na}$ convivência com a doença crônica, uma das questões refletidas durante o redimensionamento das atividades da família é a necessidade de informações a serem repassadas à criança e ao adolescente. Quando a família recebe um diagnóstico, como o do câncer, ela se vê imersa em sentimentos de perda e diante de situações complicadas. Frente à dificuldade em explicar a nova rotina, a família compromete sua relação com a criança e adolescente ao optar por não comunicar o diagnóstico à eles (VATNE; SLAUGTHER; RULAND, 2009). Algumas famílias podem considerar que a criança e adolescentes não têm capacidade cognitiva para entender a situação e, nem tão pouco, a família tem habilidade de ofertar as devidas informações que lhe permita dar esse sentido a situação vivenciada (RULAND; HAMILTON; OSMO, 2008). Assim, dúvidas sobre onde, como e quando contar para a criança tornam- se parte do cotidiano familiar, acentuando, ainda mais, o sofrimento e o estresse. Esses sentimentos tornam a capacidade de comunicar informações, ainda mais difíceis (OLIVEIRA et al., 2004). 
A comunicação médico-paciente exige do profissional grande habilidade, que envolve técnica, conhecimento teórico, ética e sensibilidade, o que se intensifica quando se trata de paciente pediátrico. Os princípios da confiabilidade e veracidade devem estar presentes na comunicação (GARRAFA; ALBUQUERQUE, 2001).

A comunicação em pediatria possui características peculiares quando comparada com a que envolve pacientes adultos, visto que a criança e adolescente estão em processo de desenvolvimento cognitivo, social e psicológico, além de possuir adultos responsáveis pela sua saúde (GARRAFA; CREPALDI, 2011). Nessa fase, é necessário haver uma aproximação e maior abertura para o diálogo entre família e profissionais de saúde.

Milbrath et al. (2011), em estudo de caráter qualitativo cujo objetivo foi discutir o processo de comunicação entre equipe de saúde e família, utilizaram de entrevistas semiestruturadas com as famílias. Os resultados revelaram que os profissionais de saúde fazem uso de uma linguagem pouco conhecida pelo senso comum, o que angustia, ainda mais, os familiares da criança e do adolescente. Para os autores, nesse processo, devem pensar nas palavras utilizadas quando constroem uma relação dialógica com as pessoas que desejam cuidar. Esses autores ainda argumentam que os vocabulários precisam ser estudados antes de serem proferidos de forma que ocorra, de fato, um diálogo. Concluíram que para que um efetivo processo comunicacional, as pessoas envolvidas no diálogo precisam compreender umas as outras, pois, caso um dos integrantes da comunicação não compreenda, ele não ocorrerá.

Em estudo de revisão realizado por Tates e Meeuwesen (2001) sobre comunicação médico-paciente pediátrico foi verificada a não participação da criança e adolescente no processo. Para os autores, alguns profissionais de saúde consideram desnecessário informa-los sobre a doença, bem como conhecer suas opiniões, avaliando ser prejudicial oferecer informações para esses pacientes, acreditando que podem não querer colaborar com o tratamento. Diante disso, os profissionais delegam à família a responsabilidade de revelar ou não o diagnóstico para a criança e adolescente.

Em relação à pessoa que deve comunicar à criança e ao adolescente sobre a doença e o tratamento, todas as mães indicaram os próprios pais, após terem recebido a notícia dos membros da equipe de saúde, notadamente do médico. Relataram ainda que os pais são pessoas próximas dos filhos, com os quais já têm um vínculo fortemente estabelecido, conseguindo, portanto, abordar o tema de melhor forma, ou seja, comunicar a má notícia de modo a não causar tanto impacto negativo na vida de seu filho; ao mesmo tempo, conseguem dar apoio e conforto em momento tão difícil. Assim, a comunicação que os pais estabelecem 
com o filho tem o objetivo de convencê-lo da importância de participar e colaborar no processo de descoberta da doença e no percurso do tratamento:

(...) eu também acho que os pais é que são estruturas da criança, acho que eles tem que saber, porque o tratamento, a caminhada é muito longa. (...) então acho que o pai e a mãe devem chegar com jeito e falar o que vai acontecer, que é pela melhora dele. Os tratamentos são duros, é triste. Eu acho que tem que saber sim e acompanhada dos pais e também de um psicólogo, (...) eles tem que saber sim M1.1.

Eu acho que esta no direito delas saberem, é muito ruim não saber, vamos supor, você vai tirar um sangue e a pessoa esta ali coletando o sangue e você não sabe o motivo para o que é. Você esta sentindo uma dor e não sabe de onde esta vindo essa dor. Então eu acho que é um direito delas saberem sim, e eu acho que quem deve contar da melhor forma é o pai e a mãe, já conhecem a criança e sabem como falar M4.3.

(...) o meu caso, prefiro assim, a mãe fica sabendo e ela conta para o filho com jeitinho, porque no meu caso, às vezes até o que a médica falou naquela hora não era certo, ela também não tinha certeza porque era um tumor raro, então, abalou eu que sou uma pessoa adulta, ele que é um adolescente em formação eu acho que abala muito mais (...) M7.1.

A família tem sido um importante canal de comunicação entre o médico, a criança e o adolescente, intermediando essas relações, especialmente na comunicação do diagnóstico, fornecendo informações a respeito da doença e preparando-os emocionalmente para o impacto das demais notícias (GEOVANINI, 2011).

Em estudo realizado por Gabarra e Crepaldi (2011), cujo objetivo foi descrever a comunicação médico-paciente pediátrico-família na perspectiva de crianças com doença crônica, elas relataram que se sentem excluídas da comunicação médico-família e consideraram imprescindível o papel mediador do membro familiar para comunicar uma má notícia, sendo este, na maioria das vezes, a mãe. Para os autores, as mães exerce papel de destaque como transmissora principal de informação aos filhos no processo de comunicação de uma má notícia, tanto sobre a doença quanto sobre a hospitalização.

Estudos nacionais (ARMELIN et al., 2005; MARCON, 2003; MEDEIROS, 2007; OLIVEIRA et al., 2004) identificaram que no atendimento pediátrico, a comunicação médica ocorre entre o profissional e os pais, principalmente a mãe, enquanto a criança é excluída. As informações sobre a saúde e a doença da criança são fornecidas pelos pais e a relação médicopaciente pediátrico restringe-se ao contato afetivo (GABARRA; CREPALDI, 2011). Estudo realizado por Hart e Chesson (1998) evidenciou que isso pode decorrer do fato de alguns 
profissionais não sabem como abordar verbalmente a criança e o adolescente; outros, apesar de terem interesse naquilo que eles pensam e desejam, tentam protegê-los de informações médicas para não perturbá-los emocionalmente.

Por meio do material empírico identificamos relatos de mães que buscam proteger os filhos, por um certo momento, em relação a comunicar uma má notícia, seja o diagnóstico do câncer, os procedimentos invasivos, a recidiva e a transferência do cuidado curativo para o paliativo. Isso pode acontecer até mesmo por dificuldade da mãe em revelar tal notícia para o seu filho, até porque ela também precisa compreender tal notícia. Também é evidente que a criança e o adolescente percebem que algo diferente está acontecendo; eles sentem as mudanças em seu organismo e corpo e também captam as atitudes e comportamentos de seus pais e da equipe de saúde:

(...) as vezes não estamos preparadas para falar naquele momento, é como naquele dia, eu não falei, só que ele ouviu eu conversar com outras pessoas, ele ficou muito nervoso, ele ficou sem dormir e eu não conseguia falar com ele, então, eu tive que primeiro falar comigo, eu tive que me entender e me acalmar para depois falar, eu só fui conseguir falar com ele na sexta-feira e ele ficou de quinta-feira para sexta-feira a noite inteira sentado na cama M7.3.

Eu acho que eu deveria saber primeiro e depois até o médico falar junto comigo com ele, na minha presença M7.1.

O que acontece é que ela vai montando o quebra-cabeça, ela foi prestando atenção e juntando como um quebra cabeça. Foi analisando a conversa e foi na hora que a psicóloga chegou nela e foi perguntando para ela e ela disse que tinha leucemia e eu não tinha contado para ela M4.2.

Em estudo realizado por Ranzani (2009) foi identificado que os profissionais de saúde incentivam a comunicação da família com a criança e adolescente, como forma de evitar que eles tenham informações de terceiros que possam causar, mais do que angústia e sofrimento, o sentimento de estar sendo enganado pela própria família. Nesse contexto, a comunicação é vista como uma relação interpessoal que envolve trocas verbais e não verbais de diversas naturezas, construindo um importante relacionamento terapêutico entre profissional-famíliapaciente pediátrico. Desta forma, a família é vista como o elo da comunicação e fonte de apoio emocional na vivência da doença (RODRIGUES; FERREIRA; MENEZES, 2010).

Claffin e Barbarin (1991) salientam que a busca por proteção, evitando comunicar à criança e ao adolescente sua doença, é equivocada, pois é impossível protegê-lo totalmente ocultando informações, tendo em vista as evidências que ele experiencia em seu corpo, a mudança de rotina e o tratamento ao qual necessita ser submetido. 
Young, Dixon-Woods e Windridge (2003) realizaram estudo com crianças e adolescente com câncer e identificaram que o diagnóstico foi primeiramente revelado pelos médicos aos pais, sem a presença do filho. Os autores argumentaram que a criança e adolescente sabe que algo está acontecendo com ele, apreendendo, por meio da comunicação não verbal e da realização dos procedimentos, a complexidade de sua doença; fazendo perguntas, pede esclarecimentos para a confirmação de algo que já sabe.

No presente estudo, as mães mencionaram dificuldades em abordar o filho para a comunicação sobre a doença, mas, mesmo assim, preferem realizar tal comunicação no hospital, no momento em que inicia o tratamento da criança e/ou do adolescente, pois têm o apoio da equipe de saúde, com a participação do médico, da enfermagem e do psicólogo no momento de transmitir a má notícia para o filho:

(...) porque ele ficou sabendo no mesmo momento por mim e pelos médicos, porque tinha um psicólogo ali junto também acompanhando, eles passaram para nós o que estava acontecendo e explicaram o jeito que ia ser o tratamento, os riscos, os benefícios, então ao mesmo tempo que foi passado e foi um choque, também foi um alívio porque nós sabíamos que ali ia ter um tratamento para o problema dele M7.3.

Eu acho que tem que ser os pais junto com alguém que cuida da criança, do adolescente, como o médico, o psicólogo, juntos, porque é uma notícia muito...., que abala mesmo M1.3.

(...) acho que tem que falar e eu acho que tem que ser a mãe junto com o médico e o jeito de falar, tem que ser uma linguagem que ele entenda M6.2.

Na relação comunicacional com o profissional de saúde, Ranzani (2009) argumenta em estudo com mães de crianças e adolescente em condição crônica, que a dúvida mais presente nas famílias é qual o melhor momento da revelação do diagnóstico para a criança. A autora expõe o medo e anseio das mães quanto à reação negativa da criança e do adolescente ao conhecer sua realidade. Nesse contexto, a fim de esclarecer as dúvidas da família e incentivá-la a estabelecer uma comunicação com a criança e adolescente, o profissional de saúde apoia, escuta e transmite as informações para o núcleo familiar fazendo com que o mesmo se capacite emocional e teoricamente para estabelecer com a criança e adolescente uma comunicação efetiva (RULAND; HAMILTON; OSMO, 2008).

Os pais são vistos como os controladores de informações, colocando limites nas mensagens a serem transmitidas aos filhos. Para Borges (2013), eles se consideram maestros a reger as informações a serem repassadas aos filhos. Assim, ao serem questionados por eles 
sobre os procedimentos e o motivo de estarem vivenciando tais situações, privilegiam transmitir apenas mensagens de esperança e encorajamento.

Na prática clínica, convivendo e cuidando de crianças e adolescentes com câncer, é perceptível que, quando cientes de seu quadro clínico, apresentam melhor aceitação e adesão ao tratamento e aos procedimentos, pois compreendem o processo de diagnóstico e terapia com vistas à cura da doença. Tal observação foi referendada pelas mães participantes do estudo:

Eu como mãe eu não queria mas se eu tivesse escondido dele hoje talvez ele não tivesse com essa garra, desse jeito que ele esta hoje, ele conseguiu lidar com o problema e achar uma solução do jeito dele, (...) e ele achou o jeito dele de superar isso. Só que eu acho que família é muito importante nessa hora, porque se ele estivesse sozinho talvez ele não conseguisse M7.1.

Tem que se envolver com o tratamento M7.3.

(...) porque ele [o adolescente] falava: tem que fazer quimioterapia, então eu vou fazer, se é para sarar eu vou fazer. Ele aceitou bem fazer M7.1.

Em estudo qualitativo realizado por Nova, Vegni e Moja (2005) foi identificada a pouca participação da criança na comunicação durante os atendimentos médicos. As crianças participantes do estudo, no entanto, demonstraram ser ativas e tentavam se comunicar com os adultos, pais e médicos, sobre sua experiência subjetiva do processo de adoecimento. Os resultados apontaram para o fato de que as crianças tinham autonomia no seu processo de aprendizagem e interiorizaram conhecimentos médicos, sendo capazes de informar espontaneamente, ou quando solicitadas, sobre seu estado de saúde.

Um aspecto fundamental para o estabelecimento de uma boa relação médico paciente é a troca de informações, pois, cada vez mais, os pacientes querem participar das decisões sobre o seu tratamento e, para tanto, recorrem aos médicos e à equipe de saúde em busca de elementos para a tomada de decisão (RIBA, JUVER, 2008). Particularmente, tratando-se de pais e crianças e adolescentes com câncer, o estabelecimento de uma comunicação propicia tanto a um quanto ao outro condições de adaptações às mudanças ocorridas no contexto do câncer infantil. A comunicação entre pais e filhos nem sempre ocorre de forma instantânea, é fruto de um processo contínuo (CLAAR; WALKER; SMITH, 2002; VASCONCELOS, 2006).

É por meio da comunicação que família e criança e adolescente criam vínculo com o profissional de saúde, estabelecendo com este uma relação de segurança e confiança. Essa 
habilidade, quando bem desenvolvida, auxilia a família na comunicação com a criança e adolescente, visto que ela está mais familiarizada com a doença e, consequentemente, saberá responder aos questionamentos feitos pela mesma. Isso acontece, mesmo sendo considerado pela família, um momento difícil e complexo (METCALFE et al., 2008; NIEWEGLOWSKI; MORE, 2008).

No percurso da doença, o papel dos pais no processo comunicativo com o filho é destacado e defendido, graças ao fato de que são eles que possuem vínculo e conhecem as necessidades e comportamentos dos filhos. Estas, são razões pelas quais os profissionais de saúde consideram os pais os mais indicados para se aproximar e oferecer explicações à criança e ao adolescente com câncer. Para que isso aconteça, é necessário que a família tenha clareza e conhecimento da situação, sentindo-se segura e confiante na transmissão de informações (GABARRA; CREPALDI, 2011).

A comunicação com características terapêuticas, contribui para o desenvolvimento do cuidado e qualifica a assistência. No entanto, somente será estabelecida uma comunicação de maneira efetiva quando houver respeito à criança e ao adolescente, compreendendo-o como ser humano, único e individual, inserido no contexto familiar e com necessidades biológicas, psicológicas, sociais, culturais e espirituais a serem atendidas (MARTINEZ et al., 2010).

Meade, Lumley e Casey (2001) referem ser importante compartilhar informações com a criança sobre a doença, tratamento e procedimentos, pois elas ampliam sua compreensão e desenvolvem maior capacidade para perceber e identificar seus sentimentos e sintomas. A comunicação estabelecida com a criança e adolescente potencializa a colaboração do mesmo no tratamento e minimiza o estresse causado pela mudança de rotina (CLARKE; FLETCHER, 2003; HILDENBRAND et al., 2011). Claar, Walker e Smith (2002) argumentam que a comunicação da família com a criança e adolescente pode ser um recurso para a preparação mais adequada e efetiva no sentido de reduzir o medo e a ansiedade decorrentes da enfermidade. Portanto, a comunicação efetiva com a criança e adolescente torna-se imprescindível para que ele possa compreender o processo de adoecimento e tratamento (GABARRA; CREPALDI, 2011). Sendo assim, quando as situações são reveladas de maneira clara, a criança e o adolescente se sentem à vontade para expor seus sentimentos e dúvidas com relação à doença, o que pode indicar que a comunicação é uma ferramenta essencial para enfrentar o diagnóstico e tratamento (LEVETOWN et al., 2008).

Diante disso, a realidade precisa tomar rumos diferentes, tendo em vista que compreender as concepções da doença, a partir do próprio discurso da criança e do 
adolescente, auxiliaria tanto na promoção da humanização nos contextos de saúde, quanto facilitaria ou ampliaria os caminhos de diálogo entre a criança, adolescente e os profissionais de saúde, auxiliando no desenvolvimento de estratégias eficazes de comunicação de acordo com cada idade (NUSSBAUM, RAGAN, WHALEY, 2003; OUTSUBO, BECKER, 2005).

Cabrera (1995) considera que a comunicação efetiva entre a tríade paciente pediátricopais-médicos pode auxiliar a criança e adolescente, e a família, principalmente por proporcionar autonomia para o seu próprio cuidado. DiMatteo (2004) assinala que a comunicação sobre o tratamento com o paciente pediátrico e a família é fundamental na adesão aos regimes terapêuticos, essenciais nas condições crônicas, principalmente no câncer. Nesse sentido, a criança e o adoelscente precisam compreender os aspectos do tratamento e as repercussões do adoecimento em sua vida, de forma que seja também corresponsável nesse processo de tratamento, ao lado da família e da equipe de saúde.

\subsection{Comunicação dos cuidados paliativos}

Nos casos de prognósticos difíceis e de transferência do tratamento de cuidados curativos para paliativos, com a confirmação do avanço progressivo da doença, detectamos dificuldades enfrentadas por médicos e familiares na comunicação dessa má notícia. Isso é evidente em nossa prática clínica como enfermeiras, tendo sido também observado durante a realização dos grupos focais. Na maioria das vezes, a comunicação à família a respeito do ingresso da criança e adolescente nos cuidados paliativos é realizada pelo médico tardiamente, considerando sua dificuldade para tal tarefa, em especial quando se trata de crianças e adolescentes:

O tumor não reagiu à quimioterapia, continuou lá firme e forte, então essa notícia para mim foi muito difícil, não ter mais o que fazer M7.1.

(...) e ela esta melhor assim sem dor, mas ainda esta com o tumor, (...) e eu falei enquanto houver vida e esperança eu estou correndo atrás, eu não vou parar jamais. Seja lá o que acontecer, que esta nas mãos de Deus. Eu e os médicos estamos cuidando também, fazendo o que podemos M1.3.

Entre os principais fatores responsáveis por tamanha dificuldade, podemos incluir a falta de preparo para o desenvolvimento desta habilidade durante os cursos de graduação em 
medicina, bem como a angústia e o temor da morte, inerentes à condição humana, especialmente presentes entre estes profissionais de saúde, notadamente no atendimento ao complexo cuidado com crianças e adolescentes (GEOVANINI, 2011).

Vivenciar a proximidade da morte é uma experiência única, acompanhada de intensa carga emocional. Frente às situações de incertezas, dor e sofrimento, os relacionamentos são ressignificados e o contato com as pessoas, seja com familiares ou profissionais de saúde, passa a representar o cerne de um cuidado que sustenta a fé e a esperança, apoiando a vivência de momentos difíceis (ARAÚJO, 2006).

A institucionalização da filosofia dos cuidados paliativos no sistema de saúde público e privado caminha a passos lentos e a implantação destes serviços encontra inúmeras barreiras, entre elas o desconhecimento da população e a deficiência na formação dos profissionais de saúde no que diz respeito à terminalidade e cuidados paliativos (ARAÚJO, 2006).

Em 1998, a WHO, apresentou uma definição específica para os cuidados paliativos pediátricos, ou seja, a ação do cuidar ativo e total da criança e adolescente, em sua dimensão biopsicossocial, desde o início do diagnóstico da doença , aliviando o sofrimento físico, psicológico e social e prestando suporte familiar. Entretanto, considerando que as necessidades biopsicossociais progridem com o agravo da doença, de forma quase inconsciente os cuidados paliativos são direcionados para o processo de morte e morrer, ou seja, o cuidado ao final da vida. A abordagem dos cuidados paliativos, complementando, prevê a afirmação da morte como um processo normal da vida; não apressar nem adiantar a morte; alívio da dor e de outros sintomas; integração dos aspectos psicológicos, sociais e espirituais no cuidado do paciente; inclusão de uma rede de apoio ao paciente e à família, incluindo o apoio no processo de luto (WHO, 2002).

Os cuidados paliativos constituem abordagem de cuidado diferenciada, destinada a melhorar a qualidade de vida do paciente com doença avançada, sem possibilidades de cura, bem como de seus familiares, por meio de avaliação e tratamento adequados para o alívio da dor e de outros sintomas. No entanto, essa modalidade de assistência encontra-se em processo de construção e, dessa forma, suas estratégias de ação, por exemplo, a comunicação, consistem em real desafio para as equipes de saúde, principalmente para a de enfermagem, cujos profissionais permanecem junto ao leito do paciente, em tempo integral (ARAÚJO; SILVA, 2012).

A enfermagem faz uso da comunicação terapêutica, uma ferramenta utilizada para assistência eficaz aos pacientes e familiares, embasada na valoração das potencialidades do 
indivíduo a fim de solucionar problemas, reconhecer suas limitações e ajustar-se à nova realidade. Isso é possível quando a equipe oferta atenção, escuta, respeito e empatia para com o próximo (STEFANELLI; CARVALHO, 2012; VASCONCELOS, 2006), neste caso em particular com os pais, crianças e adolescentes com câncer.

Em estudo de França et al. (2013), a comunicação foi apontada pelos enfermeiros como sendo um instrumento terapêutico entre eles e esses pacientes, porque ajuda-os a entender as informações sobre a doença e a ter mais controle sobre a situação vivenciada. Os resultados também apontaram que a comunicação autêntica entre o enfermeiro e a criança e adolescente pode ocorrer inclusive nos cuidados paliativos.

Ainda, a comunicação eficaz é considerada instrumento fundamental para o cuidado integral e humanizado porque, por meio dela, é possível reconhecer e acolher, empaticamente, as necessidades do paciente, em particular, as da criança e do adolescente com câncer. Quando o enfermeiro utiliza esse instrumento de forma verbal e não verbal, permite o paciente participar das escolhas e dos cuidados específicos relacionados à sua doença (MULLAN; KOTHE, 2010).

É errônea a suposição de que não há mais nada a ser feito pelo paciente sem possibilidades de cura, pois, enquanto há vida, existe a necessidade do cuidado de enfermagem. Assim, é dever e responsabilidade do enfermeiro e da equipe acompanhar o paciente durante todo o seu tratamento, especialmente quando não é mais possível a cura e o doente é submetido a cuidados paliativos (ARAÚJO, 2006).

Observamos, no relato das mães, o impacto da comunicação da transferência dos cuidados curativos para os paliativos. Observamos ainda que elas não utilizam o termo cuidados paliativos, preferindo relatar "já não tem mais o que fazer para curar o meu filho, agora vamos aliviar a dor dele”. Esse relato não foi percebido apenas nos grupos focais, durante a coleta de dados, mas também na nossa vivência profissional, pois raramente escutamos os pais dizerem que o filho está em cuidados paliativos; em geral, os vemos dizendo que a equipe comunicou sobre o avanço da doença, informando não ser mais possível a cura e que, portanto, o filho receberá tratamento para alívio da dor e conforto:

E hoje quando o doutor falou para mim que ela não esta respondendo a nenhuma medicação e que o que podia ser feito, foi feito, não sabem mais o que fazer porque ela não reage, ela não responde a medicação, isso para mim foi o pior M8.1.

(...) o que marcou, assim tem alguns, mas o que marcou mais foi agora em 2012 que a doutora chegou para mim e disse que não ia ter mais... que as 
quimioterapias não estavam dando mais certo... que não ia ter muito jeito, que já tinha feito de tudo... M1.3.

O tratamento dele não esta obtendo resposta M4.3.

A idade que ele tem agora, não é fácil de tratar, é complicado, o caso dele já esta fora do protocolo, já saiu fora de tudo, o lugar que ele esta só complica M5.3.

A literatura ressalta a dificuldade dos médicos falarem sobre a recorrência da doença, a disseminação, o fracasso do tratamento e, notadamente, sobre a mudança do tratamento curativo para o paliativo, com o grande dilema de oferecer esperança, quando já não há (FUMIS, 2010). A comunicação da passagem do tratamento com intenções de cura, aos cuidados paliativos para pacientes e familiares, tem sido reconhecida como das mais difíceis, pois, diferentemente da revelação do diagnóstico, quando a esperança de cura está presente e na condição dos cuidados paliativos ela inexiste.

Nesse cotexto, destaca-se a comunicação inadequada da equipe de saúde com a criança e o adolescente em fase paliativa bem como com a sua família. A comunicação é um elemento indispensável aos cuidados paliativos, pois é capaz de oferecer confiança entre equipe, paciente e família, colaborando com o processo de enfrentamento da fase final da vida, geralmente vivenciada de angústia e impotência, agravada pela falta de informação e de conhecimento sobre a fase paliativa e suas características (HUBBLE et al., 2008; SELTH, 2010).

A comunicação nos cuidados paliativos vai além das palavras e do conteúdo; deve primar pela escuta atenta, o olhar e a postura. O emprego adequado desse recurso é medida terapêutica eficaz para pacientes que dele necessitam (ARAÚJO; SILVA, 2007).

Para Silva (2008), estudos têm mostrado que os médicos aprendem a lidar com a doença, mas não com o doente. Em cuidados paliativos esse é um grande problema porque a doença segue seu fluxo e o grande desafio é como lidar com o doente. A maneira como o médico comunica o diagnóstico de cuidados paliativos nos leva a pensar em um ser humano vulnerável em seus sentimentos, sem se dar conta dos efeitos emocionais que pode causar aos pacientes ao longo da doença e do tratamento oferecido, bem como aos familiares e até mesmo a si próprio.

Para Araújo e Silva (2007), muitos profissionais monstram desconhecer técnicas de comunicação terapêutica, evitando o contato verbal com pacientes que vivenciam o processo 
de morte e morrer, deles se afastando por não saberem trabalhar os sentimentos que a situação de morte iminente lhes desperta.

Estudos mostram ser pertinente que todos os membros da equipe de saúde possuam e aprimorarem suas habilidades de comunicação, uma vez que a base de seu trabalho reside nas relações humanas (SILVA, 2006). Assim, para o relacionamento interpessoal, entendido como uma interação face a face entre pessoas onde há troca recíproca de sinais, a comunicação é instrumento essencial (ARAÚJO, 2006; LITLEJOHN, 1988).

O uso de estratégias comunicacionais é o centro do suporte emocional em cuidados paliativos. Habilidades para a escuta, questionamento, exploração de sentimentos e feedback não são uma questão de personalidade ou instinto do profissional, mas ferramentas necessárias para prover conforto emocional e influenciam positivamente no ajuste psicológico do indivíduo à vivência do processo perdas e incertezas inerentes ao adoecimento e morte (LIU; MOK; WONG, 2005; MUNIZ; ZAGO; SCHWATZ, 2009; OWEN; JEFFREY, 2008). Deste modo, utilizar estratégias de comunicação para prover apoio emocional é condição sine qua non para que o cuidado integral efetivo ocorra (ARAÚJO; SILVA, 2012).

Sendo assim, habilidades de comunicação são essenciais ao profissional que convive com pacientes em cuidados paliativos, independente de sua formação básica ou área de especialidade, porque estas permitem melhor acesso e abordagem à dimensão emocional. À medida que habilidades de comunicação não são adquiridas empiricamente, faz-se urgente e necessária a capacitação destes profissionais na comunicação no processo de morte e morrer. Embora atualmente no Brasil a discussão e implantação dos princípios dos cuidados paliativos estejam em franca progressão, ainda é necessário que as instituições de ensino compreendam a importância da filosofia dos cuidados paliativos e facilitem a inclusão deste tema na estrutura curricular dos cursos da área da saúde, tanto em nível de graduação quanto de pós-graduação (ARAÚJO, SILVA, 2012). 
Ao término deste estudo, foi possível alcançar o objetivo proposto, ou seja, descrever a experiência de mães de crianças e adolescentes com câncer diante da comunicação de uma má notícia, seja ela referente ao diagnóstico do câncer, procedimentos invasivos ou cuidados paliativos.

O percurso metodológico utilizado permitiu descrever essa experiência com base nos depoimentos das mães cujos filhos vivenciaram uma situação de doença com necessidade de um cuidado complexo no decorrer do processo do diagnóstico do câncer, tratamento, procedimentos e também nos cuidados paliativos. Nesse processo, emergiram do material empírico três temas: A comunicação da má notícia, descrito com base na revelação do diagnóstico de câncer, no modo de comunicar, na compreensão diante da notícia; A revelação da notícia para a criança e adolescente, que trata da comunicação com a criança e o adolescente, os envolvidos no processo de revelação do diagnóstico, abrangendo o autocuidado e a tomada de decisão; Comunicação dos cuidados paliativos, referente à comunicação da mudança de cuidado curativo para os cuidados paliativos.

Nos grupos focais, observamos que um dos aspectos em comum foi o impacto da revelação do diagnóstico de câncer associado a sentimentos de dor, sofrimento e medo da morte, no entanto, entrelaçados pela esperança da cura. Outro aspecto identificado foi a dificuldade das mães em pronunciar a palavra câncer, muitas vezes escutamos dizerem sabe aquela doença ou ele tem um tumor. Mencionaram acreditar que a palavra câncer é amaldiçoada e atrai sentimentos negativos, e isto pode interferir no sucesso do tratamento.

Contar ou não contar sobre a doença e o tratamento foi um tema também recorrente. Para algumas mães, o filho não deveria ter conhecimento da doença e do tratamento ou participação ativa nesse processo, pois assim não sofreria. Por outro lado, observamos mães que destacaram o momento da comunicação, mesmo que o de uma má notícia, como importante para que o filho tivesse melhor adesão ao tratamento; segundo elas, tal tarefa poderia ser conduzida pelos pais, com o apoio da equipe de saúde.

Na prática clínica também observamos que a criança e adolescente com câncer, quando cientes e esclarecidos sobre o diagnóstico, tratamento, cuidados e prognóstico, apresentam maior adesão ao tratamento e à terapia proposta e melhor aceitação de sua condição crônica, com melhor enfrentamento da situação nos momentos de hospitalização e de procedimentos invasivos.

Para as mães deste estudo, as crianças e adolescentes com câncer desejam participar da comunicação sobre a sua doença e tratamento, pois assim podem fazer escolhas e tomar 
decisões junto com a equipe de saúde e familiares sobre seu processo de diagnóstico e tratamento.

Outro ponto relevante evidenciado pelos resultados foi o impacto da comunicação da transferência dos cuidados curativos para os paliativos, pois, diferentemente do momento da revelação do diagnóstico, a esperança do tratamento com a finalidade de cura não estava presente. De maneira geral, as mães não utlizam o termo cuidados paliativos, preferindo dizer “já não tem mais o que fazer para curar o meu filho, agora vamos aliviar a dor dele”.

Apesar de muitos estudos tratarem da comunicação de más notícias enquanto uma revelação feita pelo profissional médico, situação essa que também vivenciamos em nossa prática clínica, atualmente faz-se necessário rever tal conduta, uma vez que o cuidado em saúde é responsabilidade de uma equipe multiprofissional e, portanto, outros profissionais participam desse momento, sendo, então, condição sine qua non para acolher pacientes e familiares. Além disso, durante os grupos focais, pudemos identificar, nos relatos das mães, a relevância dos membros da equipe de enfermagem nesse momento e na continuidade da assistência por serem os profissionais que permanecem a maior parte do tempo em contato direto com pacientes e familiares.

A valorização de uma postura dos profissionais de saúde voltada ao cuidado humanizado exige um investimento na formação acadêmica e na atuação profissional. A preocupação com o ensino da comunicação e das estratégias utilizadas para a comunicação médico - paciente tem sido manifestada principalmente nas escolas de medicina e de saúde. Novos programas destinados a preparar estudantes de medicina e outros alunos da área da saúde a comunicar más notícias a pacientes e familiares empática e consistente devem ser elaborados e aplicados para avaliar a eficácia de uma prática clínica.

Acreditamos que o estudo possa subsidiar a reflexão a respeito de como os profissionais de saúde podem desenvolver estratégias de comunicação de más notícias que contemplem os valores e significados dos pais e das crianças e adolescentes diante do processo da revelação do diagnóstico de câncer, procedimentos invasivos e cuidados paliativos. O estudo contribui também para evidenciar a necessidade de elaborar estratégias de comunicação de uma má notícia à criança e ao adolescente, incentivando-os a participar ativamente do processo de adoecimento, com direito a ter conhecimento de sua doença e participação nas decisões que envolvem o tratamento e os cuidados a eles relacionados em conjunto com a equipe de saúde e seus pais. Nessa perspectiva, acreditamos ser necessária a produção de novos estudos desta natureza, os quais auxiliarão nesta construção. 
Acreditamos ser pertinente nossa defesa da necessidade de compreender a experiência de comunicação de más notícias com vistas à produção de cuidados em saúde que atendam às reais necessidades de crianças e adolescentes e de seus pais no processo saúde-doença. Finalmente, os resultados deste estudo podem contribuir para o desenvolvimento de estratégias de enfrentamento para esses pacientes e seus familiares, bem como para a equipe de saúde. Nesse sentido, este estudo realça a importância das instituições formadoras investirem na capacitação de seus alunos em habilidades de comunicação e relacionamento com o paciente, notadamente crianças e adolescentes e seus familiares. 
REFERÊNCIAS 
ALMANZA-MUÑOS, J. J.; HOLLAND, C. J. La comunicación de las malas noticias en La relación medico-paciente: III guía clínica práctica basada en evidencia. Rev. Sanid. Mil., México, v. 53, n. 3, p. 220-4, 1999.

ARAÚJO, M. M. T.; SILVA, M. J. P. O conhecimento de estratégias de comunicação no atendimento à dimensão emocional em cuidados paliativos. Texto Contexto Enferm., Florianópolis, v. 21, n. 1, p. 121-9, 2012.

ARAÚJO, M. M. T.; SILVA, M. J. P. A comunicação com o paciente em cuidados paliativos: valorizando a alegria e o otimismo. Rev Esc Enferm USP, São Paulo, v. 41, n. 4, p. 668-74, 2007.

ARAÚJO, M. M. T. Quando “uma palavra de carinho conforta mais que um medicamento": necessidades e expectativas de pacientes sob cuidados paliativos. 2006. 141 p. Dissertação (Mestrado) - Escola de Enfermagem, Universidade de São Paulo, São Paulo, 2006.

ARMELIN, C. B.; WALLAU, R. A.; SARTI, C. A.; PEREIRA, S. R. A comunicação entre profissionais de pediatria e a criança hospitalizada. Rev Bras Crescimento Desenvolv Hum, São Paulo, v. 15, n. 2, p. 45-54, 2005.

AYARRA, M.; LIZARRAGA, S. Malas noticias y apoyo emocional. Medicina Familiar y Comunitaria. Grupo de Comunicación y Salud de Navarra. Centro de Salud. Huarte. An Sis San Navarra, Huarte, v. 24, p. 55-63, 2001. Suplemento 2.

BAILE, W. F.; BUCKMAN, R.; LENZI, R.; GLOBER, G.; BEALE, E. A; KUDELKA, A. P. SPIKES-a six-step protocol for delivering bad news: application to the patient with cancer. Oncologist, Houston, v. 5, n. 4, p. 302-11, 2000.

BASCUÑÁN, M. L. R. Comunicación de la verdad en medicina: contribuciones desde uma perspectiva psicológica. Rev Med Chile, Santiago, v. 133, p. 693-698, 2005.

BECK, C. L. C.; GONZALES, R. M. B.; LEOPARDI, M. T. Técnicas e procedimentos de pesquisa qualitativa. In: LEOPARDI, M. T. Metodologia da pesquisa na saúde. Florianópolis: UFSC/pós-Graduação em Enfermagem, 2002. p. 223-44.

BIASOLI-ALVES, Z. M. M. A pesquisa em psicologia - análise de métodos e estratégias na construção de um conhecimento que se pretende científico. In: ROMANELLI, G.; BIASOLIALVES, Z. M. M. (Orgs.). Diálogos metodológicos sobre a prática de pesquisa. Ribeirão Preto: Legis Summa, 1998. p. 135-57. 
BOGDAN, R.; BIKLEN, S. Investigação qualitativa em educação: uma introdução à teoria e aos métodos. 2. ed. Porto: Porto Editora, 1994.

BONAMIGO, E. L.; DESTEFANI, A. S. A dramatização como estratégia de ensino da comunicação de más notícias ao paciente durante a graduação médica. Rev. Bioét., Brasília, v. 18, n. 3, p. 725-42, 2010.

BONASSA, E. M. A.; GATO, M. I. R. Terapêutica oncológica para enfermeiros e farmacêuticos. 4. ed. Rio de Janeiro: Atheneu, 2012.

BORGES, A. A. Processo comunicacional familiar no contexto do câncer infantil. $130 \mathrm{f}$. Dissertação (Mestrado). UFSCAR, São Carlos, 2013.

BRASIL. Instituto Nacional do Câncer. Câncer infantil. Rio de Janeiro: Ministério da Saúde, 2012. Disponível em: <http://www2.inca.gov.br/wps/wcm/connect/tiposdecancer/site/home/ infantil>. Acesso em: 12 jan. 2012.

BRASIL. Ministério da Saúde. Secretaria de Vigilância em Saúde. Departamento de Análise de Situação de Saúde. Plano de ações estratégicas para o enfrentamento das doenças crônicas não transmissíveis (DCNT) no Brasil. Ministério da Saúde.. Brasília, DF, 2011a.

BRASIL. Ministério da Saúde. Instituto Nacional do Câncer. Estimativas 2012: incidência de câncer no Brasil. Rio de Janeiro: INCA, 2011b.

BRASIL. Ministério da Saúde. Instituto Nacional de Câncer (INCA). Coordenação Geral de Gestão Assistencial. Coordenação de Educação. Comunicação de notícias difíceis: compartilhando desafios na atenção à saúde. Rio de Janeiro: INCA, 2010.

BRAUN, V.; CLARKE, V. Using thematic analysis in psychology. Qualitative Research in Psychology, Philadelphia, v. 3, p. 77-101, 2006.

BUCKMAN, R. A. Breaking bad news: the S-P-I-K-E-S strategy. Community Oncol, Toronto, v. 2, n. 2, p. 138-42, 2005.

CABRERA REYES, F. Autonomía limitada em la relación médico paciente. Rev chil pediatr, Santiago, v. 66, n. 2, p. 81-82, 1995.

CAMPOS, E. M. P.; RODRIGUES, A. L.; MACHADO, P.; ALVAREZ, M. Intervenção em grupo: experiência com mães de crianças com câncer. Psicol estud, Maringa v. 12, n. 3, p. 635-640, 2007. 
CARRAPA, A. S. G. C. N. Comunicar más notícias em pediatria. Dissertação 2010. Dissertação (Mestrado) - Faculdade de Medicina, Universidade do Porto, Porto, 2010.

CAVALCANTI, D. R. Comunicação do diagnóstico de doença grave (câncer) ao paciente: quem? Quando? Como? Por que? Pan-Am. Fam. Med. Clin., v. 1, 2005.

CLAAR, R. L.; WALKER, L. S.; SMITH, C. A. The influence of appraisals in understanding childrens experiences with medical procedures. J Pediatr Psychol, Washington, v. 27, n.7, p. 553-563, 2002.

CLAFLIN, C. J.; BARBARIN, O. A. Does “telling” less protect more? Relationship among age, information disclosure, and what children with cancer see and feel. J Pediatr Psychol, Washington, v. 16, n. 2, p. 169-191, 1991.

CLARKE, J. N.; FLETCHER, P. Communication issues faced by parents who have a child diagnosed with cancer. J Pediatr Oncol Nurs, Philadelphia, v. 20, n.4, p. 175-191, 2003.

CICOGNA, E. C.; NASCIMENTO, L. C.; LIMA, R. A. G. Crianças e adolescentes com câncer: experiências com a quimioterapia. Rev Latino-Am. Enferm. Ribeirão Preto, Ribeirão Preto, v. 18, n. 5, p. 1-9, set.-out. 2010.

DEBUS, M. Manual para excelencia en la investigación mediante grupos focales. Washington: Health Com Agency for International Development, 1994.

DIAZ, F. G. Comunicando malas noticias en medicina: recomendaciones para hacer de la necessidad virtud. Med Intensiva, Barcelona, v.30, n.9, p. 452-9, 2006.

DIMATTEO, M. R. (2004). The role of effective communication with children and their families in fostering adherence to pediatric regimens. Patient Educ Couns, Riverside, v. 55, n. 3, p. 339-344, 2004.

DOYLE, D.; O’CONNEL, S. Breaking bad news: starting palliative care. J. R. Soc. Med., v. 89, n. 10, p. 590-1, 1996.

DRUCKER, L. P. Rede de suporte tecnológico domiciliar à criança dependente de tecnologia egressa de um hospital de saúde pública. Ciênc. Saúde Coletiva, Rio de Janeiro, v. 12, n. 5, p. 1285-94, 2007. 
FIAMENGHI, J. R.; GERALDO, A.; MESSA, A. A. Pais, filhos e deficiência: estudos sobre as relações familiares. Psicol Ciênc Prof, Brasília, v. 27, n. 2, p. 236-245, 2007.

FRANÇA, J. R. F. S.; COSTA, S. F. G.; LOPES, M. E. L., NÓBREGA, M. M. L.; FRANÇA, I. S. X. Importância da comunicação nos cuidados paliativos em oncologia pediátrica: enfoque na teoria humanística de enfermagem. Rev. Latino-Am. Enfermagem, Ribeirão Preto, v. 21, n. 3, p. 1-7, 2013.

FUMIS, R. R. L. Comunicação das más notícias: um cuidado com a saúde. Rev bras med, v. 67, p. 34-35, 2010.

GABARRA, L. C.; CREPALDI, M. A. A comunicação médico - paciente pediátrico - família na perspectiva da criança. Psicol Argum, Curitiba, v. 29, n. 65, p. 209-18, 2011.

GARRAFA, V.; ALBUQUERQUE, M. C. Enfoque bioético de la comunicación en la relación médico-paciente en las unidades de terapia intensiva pediátricas. Acta Bioeth, Santiago, v. 7, n. 2, p. 355-367, 2001

GATTI, B. A. Grupo focal na pesquisa em ciências sociais e humanas. Brasília: Líber Livro, 2005.

GEOVANINI, F. Notícias que (des) enganam: o impacto da revelação do diagnóstico e as implicações éticas na comunicação de más notícias para pacientes oncológicos. 2011. Dissertação (Mestrado) - Escola Nacional de Saúde Pública Sérgio Arouca, Rio de Janeiro, 2011.

GOFFMAN, E. Estigma: notas sobre a manipulação da identidade deteriorada. $4^{\circ}$ ed. Rio de Janeiro: LTC; 1988.

GOMES, C. H. R.; SILVA, P. V.; MOTA, F. F. Comunicação do diagnóstico de câncer: análise do comportamento médico. Rev Bras. Cancerol., Rio de Janeiro, v. 55, n. 2, p. 13943, 2009.

GON, M. C. C.; ROCHA, M. M.; GON, A. S. Análise do conceito de estigma em crianças com dermatoses crônicas. Rev bras ter comport cogn, São Paulo, v.7, n.1, p.5-20, 2005.

GONZÁLEZ, R. M. Comunicación de malas noticias: perspective enfermera. Rev. Esp. Com. Sal., Almeria, v. 1, n. 1, p. 39-49, 2010. 
GRAMLING, R.; CARROL, T.; EPSTEIN, R. M. What is known about prognostication in advanced illness? In: GOLDSTEIN, N.; MORRISON, R. S. (Orgs.). Evidence-based practice of palliative medicine. Philadelphia: Elsevier Saunders, 2013.

HAMMOND, M.; MCLEAN, E. What parents and carers think medical students should be learning about communication with children and families. Patient Educ. Couns., Liverpool, v. 76, n. 3, p. 368-75, 2009.

HART, C.; CHESSON, R. Children as consumers. BMJ, Aberdeen, v. 316, n. 7144, p. 16001603, 1998.

HILDENBRAND, A. K.; CLAWSON, K. J.; ALDERFER, M. A.; MARSAC, M. L. Coping with pediatric cancer: strategies employed by children and their parents to manage cancer-related stressors during t reatment. J Pediatr Oncol Nurs, Philadelphia, v. 28, n.6, p. 345-354, 2011.

HUBBLE, R.; TROWBRIDGE, C. H.; AHSENS, L.; WARD-SMITH, P. Effectively using communication to enhance the provision of pediatric palliative care in an acute care setting. $\mathbf{J}$ Multidiscip Healthc, Kansas, v. 1, p. 45-50, 2008.

JACOBSEN, J.; JACKSON, V. A. Communication approach for oncologists: understanding patient coping and communicating about bad news, palliative care, and hospice. J Natl Compr Canc Netw, Boston, v. 7, n. 4, p. 475-80, 2009.

JOACHIM, G.; ACORN, S. Stigma of visible and invisible chronic conditions. J Adv Nurs, Vancouver, v. 32, n. 1,p. 243-48, 2000.

KOVACS, M.; OBROSKY, D. S.; GOLDSTON, D.; DRASH, A. Major depressive disorders in youth with Insulin-Dependent Diabetes Mellitus: a controlled prospective study of course and outcome. Diabetes Care, Indianapolis, v. 20, n. 1, p. 45-51, 1997.

KOVÁCS, M. J. Comunicação em cuidados paliativos. In: PIMENTA, C. A. M.; MOTA, D. D. C. F.; CRUZ, D. A. L. M. Dor e cuidados paliativos: enfermagem, medicina e psicologia. São Paulo: Manole, 2006.

KRUEGER, R. A. Focus group: a practical guide for applied research. Newbury Park: Sage, 1988.

LEVETOWN, M. Communicating with children and families: from everyday interactions to skill in conveying distressing information. Pediatrics, Durham, v. 121, n. 5, p. 14411460, 2008. 
LEWINS, A.; SILVER, C. Using software in qualitative research: a step by step guide. Londres: SAGE Publications Inc, 2008.

LIMA, R. A. G. Experiências de pais e de outros familiares de crianças e adolescentes com câncer: bases para os cuidados paliativos. Tese (Livre-Docência). Ribeirão Preto: Escola de Enfermagem de Ribeirão Preto da Universidade de São Paulo, 2002.

LIMA, A. E. A. Cómo comunicar malas noticias a nuestros pacientes y no morir en intento. Rev Argent Cardiol, Buenos Aires, v. 71, n. 3, p. 217-20, 2003.

LITLEJOHN, S. W. Fundamentos teóricos da comunicação humana. Rio de Janeiro: Guanabara, 1988.

LIU, J. E.; MOK, E.; WONG, T. Perceptions of supportive communication in Chinese patients with cancer: experiences and expectations. J Adv Nurs, Beijing, v. 52, n. 3, p. 26270, 2005.

MACKAY, L .J.; GREGORY, D. Exploring family-centered care among pediatric oncology nurses. J Pediatr Oncol Nurs, Calgary, v. 28, n. 1, p. 43-52, 2011.

MALDONADO, M. T.; CANELLA, P. Recursos de relacionamento para profissionais de saúde: a boa comunicação com clientes e seus familiares em consultórios, ambulatórios e hospitais. Ribeirão Preto, Novo Conceito, 2009.

MAQXDA. Qualitative data analisys software. 2013.

MARCON, C. A consulta pediátrica e os aspectos comunicacionais entre o médico residente, a criança e sua família. Dissertação (Mestrado em Psicologia). $150 \mathrm{f}$. Universidade Federal de Santa Catarina, Florianópolis, 2003.

MARTINEZ, E. A.; TOCANTINS, F. R.; SOUZA, S. R. Comunicação e assistência de enfermagem a criança. Rev pesq: cuid fundam, p. 12-14, 2010.

MEADE, J. A.; LUMLEY, M. A.; CASEY, R. J. Stress, emotional skill, and illness in children: the importance of distinguishing between children $\mathrm{s}$ and parent $\mathrm{s}$ reports of illness. J Child Psychol Psychiat, v. 42, n. 3, p. 405-412, 2001. 
METCALFE, A.; COAD, J.; PLUMRIDGE, G. M.; GILL, P.; FARNDON, P. Family communication between children and their parents about inherited genetic conditions: a meta-synthesis of the research. Eur J Hum Genet, v. 16, n. 10, p. 1193-1200, 2008.

MILBRATH, V. M.; SIQUEIRA, H. C. H.; MOTTA, M. G. C.; AMESTOY, S. C. Comunicação entre a equipe de saúde e a família da criança com asfixia perinatal grave. Texto Contexto Enferm, Florianópolis, v. 20, n. 4, p. 726-734, 2011.

MINAYO, M. C. S. O desafio do conhecimento: pesquisa qualitativa em saúde. 8. ed. São Paulo: Hucitec, 2004.

MULLAN, B. A.; KOTHE, E. J. Evaluating a nursing communication skills training course: The relationships between selfrated ability, satisfaction, and actual performance. Nurse Educ Pract, Sydney, v. 10, n. 6, n. 374-8, 2010.

MUNIZ, R. M.; ZAGO, M. M. F.; SCHWATZ, E. As teias da sobrevivência oncológica: com a vida de novo. Texto Contexto Enferm, Florianópolis, v. 18, n. 1, p. 25-32, 2009.

NELSON, A. E. Family management styles: use with families whose children have cancer: proceedings of APON's 6th annual state of the science and practice preconference session samily management styles. J Pediatr Oncol Nurs, Philadelphia, v. 23, n.11, p. 236- 247, 2006.

NIEWEGLOWSKI, V. H.; MORÉ, C. L. O. O. Comunicação equipe-família em unidade de terapia intensiva pediátrica: impacto no processo de hospitalização. Estud Psicol, Campinas, v. 25, n. 1, p. 111-22, 2008.

NÓBREGA, R. D.; COLlET, N.; GOMES, I. P.; HOLANDA, E. R.; ARAÚJO, Y. B. Criança em idade escolar hospitalizada: significado da condição crônica. Texto Contexto Enferm, Florianópolis, v. 19, n. 3, p. 425-33, 2010.

NORONHA, M. G. R. C. S.; CARDOSO, P. S.; MORAES, T. N. P.; CENTA, M. L. Resiliência: nova perspectiva na promoção da saúde da família? Ciênc Saúde Coletiva, Rio de Janeiro, v. 14, n. 2, p. 497-506, 2009.

NORRIS, J. M.; MOULLES, N. J.; PELLETIER, G.; CULOS-REED, S. N. Families of young pediatric cancer survivors: a cross-sectional survey examining physical activity behavior and health-related quality of life. J Pediat Oncol Nurs, Calgary, v. 27, n. 4, p. 197-208, 2010. 
NOVA, N.; VEGNI, E.; MOJA, E. A. The physician patient-parent communication: A qualitative perspective on the child's contribution. Patient Educ Couns, v. 58, n. 3, p. 327333, 2005.

NUÑEZ, S.; MARCO, T.; BURILLO-PUTZE, G.; OJEDA, J. Procedimientos y habilidades para la comunicación de las malas noticias en urgencias. Med Clin, v. 127, n. 15, p. 580-3, 2006.

NUSSBAUM, J. F.; RAGAN, S.; WHALEY, B. Children, older adults, and women: impact on provider-patient interaction. In: THOMPSON, T. L.; DORSEY, A. M.; MILLER, K. I.; PARROTT, R. In: Handbook of health communication. Mahwah: Lawrence Erlbaum Associates, 2003.

OLIVEIRA, V. Z.; OLIVEIRA, M. Z.; GOMES, W. B.; GASPERIN, C. Comunicação do diagnóstico: implicações no tratamento de adolescentes doentes crônicos. Psicol Estud, Maringa, v. 9, n. 1, p. 9-17, 2004.

ORGANIZAÇÃO MUNDIAL DA SAÚDE (OMS). Cuidados inovadores para condições crônicas: componentes estruturais de ação. Relatório Mundial. Brasília, DF: OMS, 2002.

OUTSUBO, A. P. N.; BECKER, E. Crianças com doenças crônicas falam sobre doença: uma pesquisa exploratória. Cad pós grad disturb desenv, v. 5, p. 39-46, 2005.

OWEN, R.; JEFFREY, D. Communication: common challenging scenarios in cancer care. Eur J Cancer, v. 44, n. 8, p. 1163-8, 2008.

PAI, A. L.; PATIÑO-FERNANDEZ, A. M.; MCSHERRY, M.; BEELE, D.; ALDERFER, M. A.; REILLY, A. T.; HWANG, W. T.; KAZAK, A. E. The psychosocial assessment tool (PAT2.0): psychometric properties of a screener for psychosocial distress in families of children newly diagnosed with cancer. J Pediatr Psychol, Philadelphia, v. 33, n. 1, p. 50-62, 2010.

PANTELL, R. H.; STEWART, T. J.; DIAS, J. K.; WELLS, P.; ROSS, A. W. Physician communication with children and parents. Pediatrics, v. 70, n. 3, p. 396-402, 1982.

PEDRO, I. C. S. Apoio social e rede social às famílias de crianças com câncer. 2008. 155 f. Dissertação (Mestrado em Enfermagem) - Escola de Enfermagem de Ribeirão Preto, Universidade de São Paulo, Ribeirão Preto, 2008. 
PEREIRA, M. A. G. Má notícia em saúde: um olhar sobre as representações dos profissionais de saúde e cidadãos. Texto Contexto Enferm, Florianópolis, v. 14, n. 1, p. 33-7, 2005.

PEROSA, G. B.; RANZANI, P. M. Capacitação do médico para comunicar más notícias à criança. Rev Bras Educ Med, Rio de Janeiro, v. 32, n. 4, p. 468-73, 2008.

PINHEIRO, E. M.; BALBINO, F. S.; BALIEIRO, M. M. F. G.; DE DOMENICO, E. B. L.; AVENA, M. J. Percepções da família do recém - nascido hospitalizado sobre a comunicação de más notícias. Rev Gaúcha Enferm, Porto Alegre, v. 30, n. 1, p. 77-84, 2009.

POLIT, D. F.; BECK, C. T. Nursing research: principles and methods. 7th ed. Philadelphia: Lippincott Williams \& Wilkins, 2004.

RABUSKE, M. M. (2004).O processo comunicativo em familias com crianças e adolescentes doentes crônicos. Dissertação (Mestrado em Psicologia). Universidade Federal de Santa Catarina, Florianóplois, 2004.

RANZANI, P. M. O processo de comunicação médico/familiar/ criança: a percepção de mães de crianças portadoras de doenças crônicas graves. 2009. 109 f. Dissertação (Mestrado em Medicina). Faculdade de Medicina, Universidade Estadual Paulista "Júlio de Mesquita Filho”, Botucatu, 2009.

RIBA, J. P. C; JUVER, J. Como dar as más notícias. In: SALTZ, E.; JUVER, J. Cuidados paliativos em oncologia. Rio de Janeiro: SENAC, 2008.

RIBEIRO, R. L. R.; ROCHA, S. M. M. Enfermagem e famílias de crianças com syndrome nefrótica: novos elementos e horizontes para o cuidado. Texto Contexto Enferm, Florianópolis, v. 16, n. 1, p. 112-9, 2007.

RIDER, E. A.; VOLKAN, K.; HAFLER, J. P. Pediatric residents' perceptions of communication competencies: implications for teaching. Med Teach, Boston, v. 30, n. 7, p. 208-17, 2008.

RODRIGUES, M. V. C.; FERREIRA, E.D.; MENEZES, T.M.O. Comunicação da enfermeira com pacientes portadores de câncer fora da possibilidade de cura. Rev enfermUERJ, Rio de Janeiro, v. 18, n. 1, p. 86 -91, 2010.

RUIZ-MORAL, R. Relación médico-paciente: desafios para la formación de profesionales de la salud. Interface, Botucatu, v. 11, n. 23, p. 619-623, 2007. 
RULAND, C. M.; HAMILTON, G. A; OSMO, B. S. The complexity of symptoms and problems experienced in children with cancer: a review of the literature. J Pain Symptom Manage, Oslo, v. 37, n. 3, p 403-418, 2008.

SANCHO, M. G. Cómo dar las malas noticias em medicina. 3. ed. Madrid: Arán, 2006.

SELTH, T. Communication to pediatric cancer patients and their families: a cultural perspective. Indian J Palliative Care, Mumbai, v. 16, n. 1, p. 26-29, 2010.

SILVA, M. J. P. Falando da comunicação. In: CREMESP. Cuidado paliativo. São Paulo, 2008.

SILVA, M. J. P. Comunicação tem remédio: a comunicação nas relações interpessoais em saúde. 4 ed. São Paulo: Loyola, 2006.

SILVA, M. J. P. Comunicação com pacientes fora de possibilidades terapêuticas: reflexões. Mundo Saúde, v. 27, n. 1, p. 64-70, 2003.

SILVA, M. J. P. O papel da comunicação na humanização da atenção à saúde. Rev. Bioética, v. 10, n. 2, p. 73-88, 2002.

SILVA, V. C. E.; ZAGO, M. M. F. A revelação do diagnóstico de câncer para profissionais e pacientes. Rev Bras Enferm, v. 58, n. 4, p. 476-80, 2005.

STEFANELLI, M. C.; CARVALHO, E. C. A comunicação nos diferentes contextos da enfermagem. In:

Manole, 2012. p. 65-77.

SONTAG, S. A doença como metáfora. Rio de Janeiro: Graal, 1984.

TATES, K.; MEEUWESEN, L.; ELBERS, E.; BENSING, J. I've come for his throat: roles and identities in doctor-parent-child communication. Child Care Health Dev, v. 28, n. 1, p. 109-16, 2002.

TATES, K.; MEEUWEESEN, L. Doctor-parent-child communication: a (re)view of the literature. Soc Sci Med, v. 52, n.6, p. 839-851, 2001.

TRAVALINE, J. M.; RUCHINSKAS, R.; D’ALONZO, G. E. Patient-physician communication: why and how? J Am Osteopath Assoc, v. 105, n. 1, p. 13-18, 2005. 
TURATO, E. R. Métodos qualitativos e quantitativos na área da saúde: definições, diferenças e seus objetos de pesquisa. Rev Saúde Pública, São Paulo, v. 39, n. 3, p. 507-14, 2005.

TWYCROSS, R. Cuidados paliativos. 2. ed. Lisboa: Climepsi, 2003.

VALLE, E. R. M.; RAMALHO, M. A. N. O câncer na criança: a difícil trajetória. In: CARVALHO, V. A. et al. (Orgs.). Temas em psico-oncologia. São Paulo: Summus, 2008.

VANDEKIEFT, G. K. Breaking bad news. Am Fam Phys, v. 64, n. 12, p. 1975-9, 2001.

VASCONCELOS, S. G. Comunicação entre mãe-filho em alojamento conjunto à luz dos fatores proxêmicos. 2006. 78 f. Dissertação (Mestrado em Enfermagem ClínicoCirúrgico). Universidade Federal do Ceará, Ceará, 2006.

VATNE, T. M; SLAUGTHER, L; RULAND, C. M. How children with cancer communicate and think about symptoms. J Pediatr Oncol Nurs, v. 27, n. 1, p. 25-32, 2009.

VICTORINO, A. B.; NISENBAUM, E. B.; GIBELLO, J.; BASTOS, M. Z. N.; ANDREOLI, P. B. A. Como comunicar más notícias: uma revisão bibliográfica. Rev. SBPH, v. 10, n. 1, p. 1-11, 2007.

VIEIRA, M. A.; LIMA, R. A. G. Crianças e adolescentes com doença crônica: convivendo com mudanças. Rev Latino-Am Enferm, Ribeirão Preto, v. 10, n. 4, p. 552-60, 2002.

Cancer. Geneva, 2012. Disponível em: <http://www.who.int/mediacentre/factsheets/ fs297/en/> Acesso em: 19 dez. 2012.

WORLD HEALTH ORGANIZATION. WHO. National cancer control programmes: policies and managerial guidelines. 2. ed. Geneva: WHO, 2002

WORLD HEALTH ORGANIZATION. WHO. Cancer pain relief and palliative care in children. Geneva, 1998.

WONG, D. L. Fundamentos de enfermagem pediátrica. 7. ed. Rio de Janeiro: Elsevier, 2006.

YOUNG, B.; DIXON-WOODS, M.; WINDRIDGE, K. C. Managing communication with young people who have a potentially life threatening chronic illness: qualitative study of patients and parents. BMJ, v. 326, p. 305-309, 2003. 
APÊNDICES 


\section{APÊNDICE I}

\section{TERMO DE CONSENTIMENTO LIVRE E ESCLARECIDO}

Título da Pesquisa: Comunicação de más notícias: experiência de mães e pais de crianças e adolescentes com câncer

Prezado (a) Senhor (a),

Meu nome é Talitha Bordini de Mello, sou enfermeira e aluna de mestrado do Programa de Pós Graduação Enfermagem em Saúde Pública da Escola de Enfermagem de Ribeirão Preto da Universidade de São Paulo e gostaria de convidá-lo (a) a participar de uma pesquisa que será realizada aqui no Hospital das Clínicas. A minha orientadora é a Profa. Regina Aparecida Garcia de Lima, enfermeira e professora da Escola de Enfermagem de Ribeirão Preto da Universidade de São Paulo. O objetivo é conhecer como o senhor (a) vivencia a comunicação de notícias difíceis sobre a doença de seu filho (a) (ao diagnóstico, aos procedimentos invasivos - como implante de cateter venoso central, cirurgias - , agravamento da doença, e mudança do cuidado curativo para o paliativo). Caso o senhor (a) concorde com a participação terá que responder a perguntas sobre a comunicação de má notícia durante uma entrevista que será realizada aqui no Hospital das Clínicas e poderá ter a duração de 15 a 30 minutos. O senhor (a) não será identificado (a) e as informações fornecidas serão mantidas em segredo, por exemplo, sem saber o que o senhor (a) nos disse. Se o senhor (a) não quiser responder a alguma pergunta, não terá problema. Caso o senhor (a) não queira participar, não haverá qualquer prejuízo para o tratamento do seu filho (a) e para o senhor (a). O senhor (a) não terá nenhum benefício direto, nesse momento, pela sua participação, mas os resultados do estudo contribuirão para a compreensão da experiência de comunicação de más notícias com vistas à produção de cuidados de saúde que atendem às reais necessidades de seu filho (a) com câncer e do senhor (a). Na sua participação não estão previstos riscos, se sentir qualquer desconforto pode solicitar para encerrar a entrevista, continuando ou não mais tarde. Quando terminarmos esta pesquisa, o resultado final poderá ser divulgado em revistas e apresentado em encontros científicos. A participação do senhor (a) é completamente voluntária e não haverá custo por esta participação.

Se o senhor (a) concordar, nossas conversas serão gravadas, para que eu não esqueça nada do que foi dito e depois passadas para o papel e se quiser o senhor (a) poderá receber uma cópia do material para conferência. Gostaríamos, também, de ter autorização para consultar o prontuário de seu filho (a) para conhecermos como tem sido a sua história clínica.

Esta pesquisa foi encaminhada ao Comitê de Ética em Pesquisa (CEP) da Escola de Enfermagem de Ribeirão Preto/USP, pois respeita as questões éticas necessárias para a sua realização. O CEP também tem a finalidade de proteger as pessoas que participam da pesquisa, como o senhor (a) e seu filho (a) e preservar seus direitos. Assim, se for necessário, entre em contato com este CEP pelo telefone (16)3602-3386. Caso deseje falar conosco, o senhor (a) poderá nos encontrar por meio do telefone (16)3602-0542 ou procurar-nos na Escola de Enfermagem de Ribeirão Preto da Universidade de São Paulo, Avenida Bandeirantes, 3900 - Campus Universitário, Ribeirão Preto - SP.

Agradecemos a sua colaboração. 
Pesquisadora principal: Talitha Bordini de Mello - Email: talibordini@gmail.com

Orientadora: Profa. Dra. Regina Aparecida Garcia de Lima - E-mail: limare@eerp.usp.br

Assinatura da pesquisadora
Assinatura do responsável

Após ter conhecimento sobre como colaborar com esta pesquisa, concordo em participar, não tendo sofrido nenhuma pressão para tanto.

Responsável - Eu, aceito participar desta pesquisa, respondendo a perguntas sobre a experiência em receber a comunicação de notícias difíceis. Sei, também, que ao final deste trabalho o meu nome será mantido em segredo e quando eu não quiser mais participar, posso interromper a entrevista. Recebi uma cópia deste documento, assinada pela pesquisadora responsável e tive a oportunidade de discuti-lo com a mesma.

Responsável pela criança/adolescente

Talitha Bordini de Mello

Mestranda
Regina Aparecida Garcia de Lima

Orientadora
Ribeirão Preto, de de 2012 


\section{APÊNDICE II}

\section{Instrumento de Coleta de Dados para as mães e os pais}

\section{Dados de identificação}

Nome:

Mãe

Sexo:

Data de nascimento:

Escolaridade:

Estado civil:

Religião:
Data:

Pai

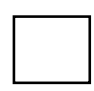

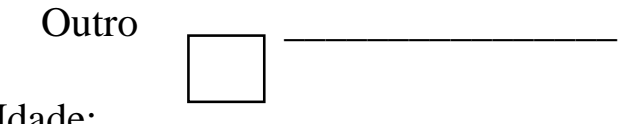

Idade:

Profissão/Ocupação:

$\mathrm{N}^{\mathrm{o}}$ de filhos/idade:

Procedência:

\section{Questões norteadoras}

O que você considera uma notícia difícil relacionada à doença de seu filho?

Qual foi a notícia difícil?

Como aconteceu a revelação da comunicação da notícia difícil?

Por quem foi feita a comunicação? Onde foi feito?

Quem participou do momento da comunicação?

Qual foi sua reação no momento da comunicação de uma notícia difícil?

Quem estava com você naquele momento?

Qual foi a sua compreensão frente à notícia?

Qual a reação do seu filho(a) diante da comunicação de notícias difíceis? Ele(a) compreendeu?

Pensando em outras famílias que tem filhos com câncer, eu gostaria de ouvir a sua opinião quanto a contar para eles. Quando se deveria contar? Como deveria comunicar? E por quem deveria ser feita a comunicação?

Você acha que a comunicação de uma notícia difícil poderia ter sido de outra forma?

Que outras experiências sobre comunicação de notícias difíceis relacionadas à doença de seu filho você teve?

O que você lembra da comunicação da notícia difícil?

O que mais marcou durante o momento em que a notícia difícil foi dada a você?

Como foi o momento após a comunicação da notícia difícil?

Você teve acompanhamento ou algum tipo de apoio após receber a notícia difícil? 
ANEXO 


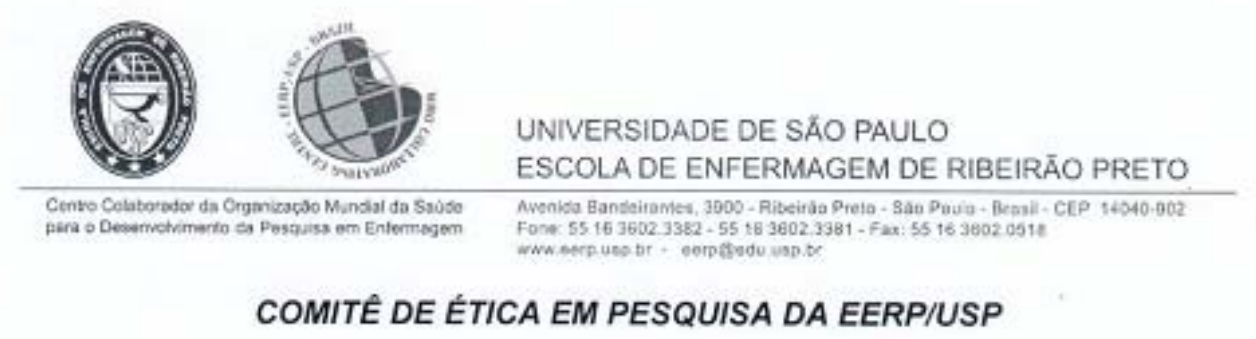

Of.CEP-EERP/USP - 111/2012

Ribeirāo Preto, 04 de junho de 2012

Prezada Senhora,

Comunicamos que o projeto de pesquisa, abaixo especificado, foi analisado e considerado APROVADO AD REFERENDUM pelo Comitê de Ética em Pesquisa da Escola de Enfermagem de Ribeirāo Preto da Universidade de Sāo Paulo, em 04 de junho de 2012.

Protocolo CAAE: 01186212.1 .0000 .5393

Projeto: Comunicação de más noticias: experiências de pais e de crianças e adolescentes com doença crônica.

Pesquisadores: Regina Aparecida Lima

Talitha Bordini de Mello

Em atendimento à Resoluçāo 196/96, deverá ser encaminhado ao CEP o relatório final da pesquisa e a publicação de seus resultados, para acompanhamento, bem como comunicada qualquer intercorrência ou a sua interrupção.

\author{
Atenciosamente,

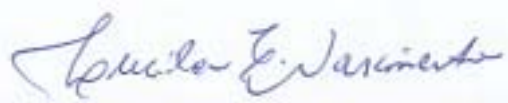 \\ Profa. Dra. Lucila Castanheira Nascimento \\ Coordenadora do CEP-EERP/USP
}

Ilma. Sra.

Profa. Dra. Regina Aparecida Lima

Departamento de Enfermagem Materno-Infantil e Saúde Pública

Escola de Enfermagem de Ribeirăo Preto - USP 